\title{
The Indirect Consequences of Expanded Off-Label Promotion
}

\author{
PATRICIA J. ZETTLER* \\ TABLE OF CONTENTS
}

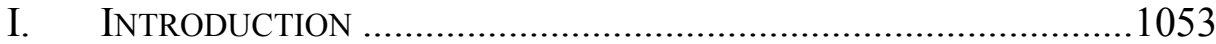

II. The OfF-LABEL PROMOTION CONTROVERSY ..............................1060

A. The FDA's Position on Off-Label Promotion .......................1061

B. Challenges to the FDA's Position .......................................1063

1. Protections for Commercial Speech ..............................1063

2. Recent Applications to the FDA's Position ...................1065

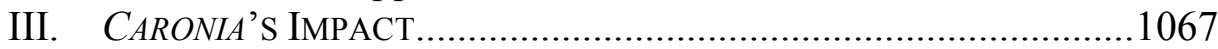

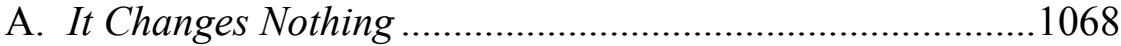

B. It Changes Everything .....................................................1070

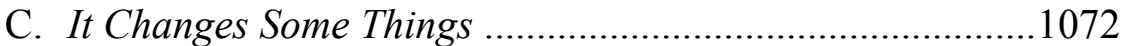

IV. EXPLORING INDIRECT CONSEQUENCES .....................................1076

A. The FDA's Regulation of New Drugs ..................................1077

1. Regulating the Practice of Medicine

Through REMS ........................................................1080

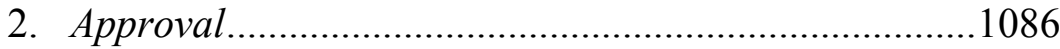

B. Other Consequences: The Example of New Tobacco Product

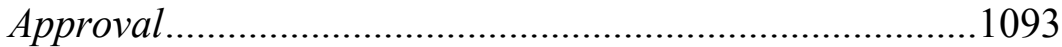

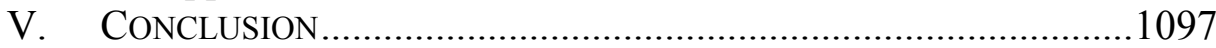

\section{INTRODUCTION}

The U.S. Food and Drug Administration (FDA) plays a vital public health role. It oversees human and animal medical products, food, dietary supplements, cosmetics, products that emit radiation, and tobacco - regulating approximately $25 \%$ of the U.S. consumer economy ${ }^{1}$ - and features prominently in many of

* Associate Professor, Georgia State University College of Law. For helpful discussion and comments, the author would like to thank Micah Berman, Russell Covey, Erika Lietzan, Lauren Sudeall Lucas, Nicholson Price, Christopher Robertson, Rachel Sachs, Nirej Sekhon, Shana Tabak, Ramsi Woodcock, the participants in the Ohio State Law Journal's symposium on "The Expanding First Amendment," the participants in the Law and the Biosciences Workshop at Stanford Law School, and the participants in the faculty workshops at the Chase College of Law at Northern Kentucky University and the University of Tennessee College of Law. Thanks also to Katelin Bassett, J.D. '18 Georgia State University College of Law, and Renate Walker, J.D. '18 Georgia State University College of Law, for their terrific research assistance.

${ }^{1}$ See, e.g., U.S. Food \& DRUg Admin., Global Engagement 2 (2012), https://www.fda.gov/downloads/aboutfda/reportsmanualsforms/reports/ucm298578.pdf [https://perma.cc/H2C3-ECHQ]. 
today's most pressing public health issues, including antimicrobial resistance, opioid misuse and overdose, and the death and disease caused by tobacco use. Speech, arguably, is integral to the FDA's regulatory scheme. ${ }^{2}$

For example, whether a product meets the definition of a drug or device within FDA jurisdiction partly depends on the product's "intended use," which is defined as the "objective intent of the persons legally responsible for the labeling" and is often determined by the manufacturer's speech about the product. ${ }^{3}$ For products that are within FDA jurisdiction, the agency extensively regulates product labeling and, in some cases, advertising. ${ }^{4}$ Additionally, speech regulation may become increasingly intertwined with certain areas of FDA regulation as innovative technologies that are designed to interpret and convey information - such as genetic tests - blur the boundaries between medical products and speech. ${ }^{5}$

Perhaps because of the agency's wide-ranging jurisdiction and that jurisdiction's extensive intersection with speech regulation, food and drug law has become a high-profile battleground for commercial speech litigation. In particular, the FDA's position that "off-label" promotion of approved prescription drugs - when a manufacturer promotes a drug for a use for which the FDA has not approved it — leads to violations of the Federal Food, Drug, and Cosmetic Act (FDCA) has been subject to successful legal challenges in the last several years. ${ }^{6}$

${ }^{2}$ See, e.g., Request for Comment on First Amendment Issues, 67 Fed. Reg. 34,943, 3,943 (May 16, 2002) ("[M]uch of the operation of the Federal Food, Drug, and Cosmetic Act ... depends on the use of words.").

321 C.F.R. § 201.128 (2016); 21 C.F.R. § 801.4 (2017); see 21 U.S.C. $\$ 321$ (2012); see also Whitaker v. Thompson, 353 F.3d 947, 953 (D.C. Cir. 2004) (declining to find that FDA's use of speech as evidence of an unapproved product's intended use violates a company's First Amendment rights). In January 2017, the FDA published a final rule amending its regulatory definition of intended use, which will go into effect in March 2018. The agency, however, is not changing the quoted language. 82 Fed. Reg. 2193, 2217 (Jan. 9, 2017); 82 Fed. Reg. 14,319, 14,319 (Mar. 20, 2017).

${ }^{4}$ See, e.g., Krista Hessler Carver, A Global View of the First Amendment Constraints on FDA, 63 FOOD \& DRUG L.J. 151, 164 (2008).

${ }^{5}$ See, e.g., Barbara J. Evans, The First Amendment Right To Speak About the Human Genome, 16 U. PA. J. Const. L. 549, 551 (2014); Robert C. Green \& Nita A. Farahany, Regulation: The FDA Is Overcautious on Consumer Genomics, 505 NATURE 286, 286 (2014); Kayte Spector-Bagdady \& Elizabeth Pike, Consuming Genomics: Regulating Direct-to-Consumer Genetic and Genomic Information, 92 NEB. L. REV. 677, 728-31 (2014); see also Rachel E. Sachs, Innovation Law and Policy: Preserving the Future of Personalized Medicine, 49 U.C. DAVIS L. REV. 1881, 1897 n.76 (2016) (“In light of recent case law, physicians may also seek to use the First Amendment against FDA enforcement efforts [with respect to certain diagnostic tests].”).

6 The FDA's policies on off-label promotion of prescription drugs are, by no means, the only FDA policies that have been subject to First Amendment challenges. Many other aspects of the FDA's regulatory scheme have also been challenged. See, e.g., Thompson v. W. States Med. Ctr., 535 U.S. 357, 366 (2002); R.J. Reynolds Tobacco Co. v. FDA, 696 F.3d 1205, 1208 (D.C. Cir. 2012); Disc. Tobacco City \& Lottery, Inc. v. United States, 674 
Some commentators view this development as a correction of the FDA's unnecessary and unconstitutional restrictions on industry speech. ${ }^{7}$ But others have argued that courts' increasing willingness to recognize and expand protection for off-label promotion will have harmful public health consequences. ${ }^{8}$ The federal government, and state and local governments, have identified troubling - at least in their view - marketing campaigns conducted by pharmaceutical companies to promote off-label uses of drugs. Examples include promoting antipsychotic drugs for use in older patients with dementia, a population in which the use of the drugs is associated with an increased risk of death; ${ }^{9}$ promoting antidepressants for use in adolescents with depression, a population in which use of the drugs is associated with an increased risk of suicidal thinking and behavior ${ }^{10}$ and marketing powerful painkillers, intended for managing breakthrough pain in patients with cancer who are opioid tolerant, for a broader patient population at a time when the United States is facing an epidemic of opioid misuse and overdose. ${ }^{11}$

F.3d 509, 520 (6th Cir. 2012); Pearson v. Shalala, 164 F.3d 650, 654 (D.C. Cir. 1999); All. for Nat. Health U.S. v. Sebelius, 714 F. Supp. 2d 48, 58 (D.D.C. 2010); Gerald Masoudi \& Christopher Pruitt, The Food and Drug Administration v. the First Amendment: A Survey of Recent FDA Enforcement, 21 HeAlth MATRIX 111, 111 (2011). But the FDA's policies on off-label promotion of prescription drugs provide a particularly high-profile example of an area in which First Amendment challenges have recently met with increased success-and, because of the public health stakes, an important example.

${ }^{7}$ See, e.g., Coleen Klasmeier \& Martin H. Redish, Off-Label Prescription Advertising, the FDA and the First Amendment: A Study in the Values of Commercial Speech Protection, 37 AM. J.L. \& MED. 315, 317 (2011); Anthony J. Anscombe \& Mary Beth Buckley, Facteau Medical Device Convictions Illustrate FDA's Unhealthy Control over Off-Label Speech, LEGAL BACKGROUNDER (Washington Legal Found., Washington, D.C.), Oct. 28, 2016, at 4, http://www.wlf.org/upload/legalstudies/legalbackgrounder/

102816LB_Anscombe.pdf [https://perma.cc/N3QP-CGJL]; cf. Lars Noah, The Little Agency that Could (Act with Indifference to Constitutional and Statutory Strictures), 93 CORNELL L. REV. 901, 920 (2008) ("[A]t times the FDA has shown a marked indifference to constitutional limits on its range of actions.").

${ }^{8}$ See, e.g., Joshua M. Sharfstein \& Alta Charo, The Promotion of Medical Products in the 21st Century: Off-Label Marketing and First Amendment Concerns, 314 JAMA 1795, 1796 (2015).

${ }^{9}$ Press Release, U.S. Dep’t of Justice, Eli Lilly and Company Agrees To Pay $\$ 1.415$ Billion To Resolve Allegations of Off-Label Promotion of Zyprexa (Jan. 15, 2009), https://www.justice.gov/archive/opa/pr/2009/January/09-civ-038.html [https://perma.cc/3WG2879F]; Press Release, U.S. Dep't of Justice, Johnson \& Johnson To Pay More Than $\$ 2.2$ Billion To Resolve Criminal and Civil Investigations (Nov. 4, 2013), https://www.justice.gov/ opa/pr/johnson-johnson-pay-more-22-billion-resolve-criminal-and-civil-investigations [https://perma.cc/MR49-UHRN].

${ }^{10}$ Press Release, U.S. Dep't of Justice, GlaxoSmithKline To Plead Guilty and Pay $\$ 3$ Billion To Resolve Fraud Allegations and Failure To Report Safety Data (July 2, 2012), https://www.justice.gov/opa/pr/glaxosmithkline-plead-guilty-and-pay-3-billion-resolvefraud-allegations-and-failure-report [https://perma.cc/AZD4-WSTK].

${ }^{11}$ See Jessica Huseman, Illinois Sues Controversial Drug Maker over Deceptive Marketing Practices, PRoPuBlica (Aug. 29, 2016), https://www.propublica.org/article/ 
Although all on-label uses of drugs also are associated with risks (and sometimes quite serious risks), ${ }^{12}$ such off-label marketing is troubling to regulators and many public health advocates for various reasons. It is wellestablished that industry promotion - both to prescribers and directly to patients - influences prescribing practices. ${ }^{13}$ Research also suggests that the majority of off-label uses lack strong scientific support, off-label uses not supported by strong scientific evidence are associated with significantly higher rates of adverse events than on-label uses are, and prescribers are often unaware that particular uses are off-label even when the benefits of those uses are unsupported. ${ }^{14}$ Promoting off-label uses, therefore, may inappropriately increase prescriptions for off-label uses that have unfavorable, or unacceptably uncertain, risk-benefit ratios. ${ }^{15}$ Indeed, scholars have asserted that the off-label promotion of certain products "has led to widespread patient morbidity and mortality." 16 Equally important, enabling the promotion of uses that the FDA

illinois-sues-controversial-drug-maker-over-deceptive-marketing-practices

[https://perma.cc/4NAM-ZAQD]; Nate Raymond, Insys Agrees To Pay \$4.45 Million To Resolve Illinois Opioid Lawsuit, REUTERS (Aug. 18, 2017), http://www.reuters.com/article/ us-insys-court/insys-agrees-to-pay-4-45-million-to-resolve-illinois-opioid-lawsuit-

idUSKCN1AY25C [https://perma.cc/UX5U-ULPX]; Understanding the Epidemic, CENTERS FOR DISEASE CONTROL \& PREVENTION, https://www.cdc.gov/drugoverdose/epidemic/ [https://perma.cc/X2E3-23US] (last updated Dec. 16, 2016).

${ }^{12}$ For example, when Zyprexa, one of the antipsychotics promoted for use in older patients with dementia, is used on-label for the indications and populations for which it is approved, it is associated with serious and potentially fatal risks such as neuroleptic malignant syndrome (NMS). See, e.g., U.S. Food \& Drug Admin., Approved Labeling for Zyprexa (Oct. 2016), https://www.accessdata.fda.gov/drugsatfda_docs/label/2017/

020592s068s069,021086s044s045,021253s057s058lbl.pdf [https://perma.cc/4SKU-SR8C].

${ }^{13}$ See, e.g., Kevin M. Fain \& G. Caleb Alexander, Mind the Gap: Understanding the Effects of Pharmaceutical Direct-to-Consumer Advertising, 52 MED. CARE 291, 292 (2014); Ashley Wazana, Physicians and the Pharmaceutical Industry: Is a Gift Ever Just a Gift?, 283 JAMA 373, 375 (2000).

${ }^{14}$ See, e.g., Donna T. Chen et al., U.S. Physician Knowledge of the FDA-Approved Indications and Evidence Base for Commonly Prescribed Drugs: Results of a National Survey, 18 Pharmacoepidemiology \& Drug SAFETy 1094, 1098 (2009); Tewodros Eguale et al., Association of Off-Label Drug Use and Adverse Drug Events in an Adult Population, 176 JAMA InTERnAL MED. 55, 60 (2016) [hereinafter Eguale, Association]; Tewodros Eguale et al., Drug, Patient, and Physician Characteristics Associated with Off-Label Prescribing in Primary Care, 172 Archive InTERnAL Med. 781, 781 [hereinafter Eguale, Drug].

${ }^{15}$ See, e.g., Aaron S. Kesselheim et al., Mandatory Disclaimers on Dietary Supplements Do Not Reliably Communicate the Intended Issues, 34 HeAlth AfF. 438, 445 (2015).

16 Aaron S. Kesselheim \& Michelle M. Mello, Prospects for Regulation of Off-Label Drug Promotion in an Era of Expanding Commercial Speech Protection, 92 N.C. L. REV. 1539,1542 (2014) (citing various sources in the medical and scientific literature regarding the consequences of the off-label marketing of Vioxx, Avandia, Paxil, and Ketek); see also Barbara J. Evans, Seven Pillars of a New Evidentiary Paradigm: The Food, Drug, and 
has not approved may eliminate important incentives for companies to study those off-label uses-meaning that the scientific evidence needed for prescribers (and the public) to understand whether a particular use is appropriate is never produced. ${ }^{17}$

Notwithstanding these concerns, courts, increasingly, have seemed willing to find that the First Amendment protects a broader range of off-label promotion than FDA policies have typically permitted. In response, commentators have suggested various ways in which public health concerns might be reconciled (or not) with the constitutional limits on the FDA's authority. Some scholars and advocates have proposed changes to the FDA's requirements for product marketing to better align agency policies with recent First Amendment decisions and make the agency less vulnerable to constitutional challenges. ${ }^{18}$ Others have questioned the assumptions that appear to underlie recent court opinions expanding industry's First Amendment rights, highlighting reasons why courts should decline to extend, or should walk back, protections for commercial

Cosmetic Act Enters the Genomic Era, 85 Notre DAME L. REV. 419, 509 (2010) (“[O]fflabel uses may be overtly dangerous or wasteful . . . . Certain 'bad' off-label uses may need to be banned.").

17 See, e.g., U.S. FoOD \& DRUG ADMIN., MEMORANDUM: PUBlic HeAlth INTERESTS AND FirST AMENDMENT CONSIDERATIONS RELATED TO MANUFACTURER COMMUNICATIONS REGARDING UNAPPROVED USES OF APPROVED OR CLEARED MEDICAL PRODUCTS 4-5 (Jan. 2017), https://www.regulations.gov/document?D=FDA-2016-N-1149-0040 [https://perma.cc/FTD8LRES] [hereinafter FDA MEMO]; Rebecca Dresser \& Joel Frader, Off-Label Prescribing: A Call for Heightened Professional and Government Oversight, 37 J.L. MED. \& ETHICS 476, 483 (2009); Rebecca S. Eisenberg, The Problem of New Uses, 5 Yale J. HeAlth Pol'y L. \& ETHICs 717, 719-20 (2005) [hereinafter Eisenberg, Problem]; Rebecca S. Eisenberg, The Role of the FDA in Innovation Policy, 13 Mich. TeleCOMM. TECH. L. REV. 345, 347 (2007); see also Erika Lietzan, The Myths of Data Exclusivity, 20 LEWIS \& CLARK L. REV. 91, 150 (2016) ("[S]ome provisions that are viewed as more traditional health-and-safety measures also implement, whether intentionally or incidentally, innovation policy.”); W. Nicholson Price II, Big Data, Patents, and the Future of Medicine, 37 CARDOZO L. REV. 1401, 1416 n.71 (2016) (discussing the "intertwined" goals of ensuring the quality, and incentivizing the innovation, of medical algorithms); cf. Yaniv Heled, Regulatory Competitive Shelters, 76 OHIO ST. L.J. 299, 301 (2015) (describing the FDA's role in supporting innovation); Anna B. Laakmann, A Property Theory of Medical Innovation, 56 JURIMETRICS 117, 157-58 (2016) ("[M]anufacturers stand to gain little from performing risky, rigorous clinical trials to study off-label uses of licensed drugs."); Jacob S. Sherkow, Patent Law's Reproducibility Paradox, 66 DuKE L.J. 845, 851 (2017) (describing the lack of incentives for researching "alternative uses to know, patented therapeutics").

18 See, e.g., Ryan Abbott \& Ian Ayres, Evidence and Extrapolation: Mechanisms for Regulating Off-Label Uses of Drugs and Devices, 64 DuKE L.J. 377, 382 (2014); Alan Bennett et al., Back to First Principles: A New Model for the Regulation of Drug Promotion, 2 J.L. \& BIOSCIENCES 168, 170 (2015); Kesselheim \& Mello, supra note 16, at 1574; see also Declaration of Scott Gottlieb, M.D. in Support of Plaintiffs' Motion for Preliminary Injunction at 15, Amarin Pharma, Inc. v. U.S. FDA, 119 F. Supp. 3d 196 (S.D.N.Y. 2015) (No. 15 Civ. 3588(PAE)) (identifying "viable, less speech-restrictive" alternatives to the FDA's off-label promotion policies). 
speech in this area. ${ }^{19}$ Possibly most troubling for those concerned about expanded protection for commercial speech, as discussed elsewhere in this Issue, courts' recent willingness to recognize First Amendment protection for off-label promotion of approved drugs also may logically extend to protecting the promotion of unapproved drugs - which would de facto permit their sale, undermining the entire premarket approval scheme for new drugs. ${ }^{20}$

This Article takes a different approach by exploring potential indirect consequences of recently recognized protections for off-label promotion. In United States v. Caronia, a high-profile 2012 case regarding off-label promotion, Judge Debra Ann Livingston's dissenting opinion cautioned that the majority's recognition of expanded protections for off-label promotion may have indirect effects - by causing the FDA's approval decisions, which must balance a drug's benefits against its risks, to "become[] very difficult or even impossible." 21 This Article argues that, as Judge Livingston suggested, protections for off-label promotion indeed might affect the FDA's decisionmaking in areas other than drug promotion, and analyzes precisely what those effects could be in light of the FDA's current statutory authority.

${ }^{19}$ See, e.g., Micah L. Berman, Manipulative Marketing and the First Amendment, 103 GeO. L.J. 497, 537 (2015); Christopher Robertson, When Truth Cannot Be Presumed: The Regulation of Drug Promotion Under an Expanding First Amendment, 94 B.U. L. REV. 545, 554-55 (2014); Spencer Phillips Hey \& Aaron S. Kesselheim, An Uninformative Truth: The Logic of Amarin's Off-Label Promotion, PLOS Med., at 1, 4 (Mar. 15, 2016), http://journals.plos.org/plosmedicine/article?id=10.1371/journal.pmed.1001978

[https://perma.cc/WYB4-8ZWS]; see also David Orentlicher, Off-Label Drug Marketing, the First Amendment, and Federalism, 50 WASH. U. J.L. \& POL'Y 89, 92 (2016) (arguing that courts have failed to account for the federalism concerns implicated by FDA regulation of off-label use).

${ }^{20}$ See Christopher T. Robertson, The Tip of the Iceberg: A First Amendment Right to Promote Drugs Off-Label, 78 OHIO ST. L.J. 1019, 1023-24 (2017) [hereinafter Robertson, Tip of the Iceberg]; infra Part III.B; see also Nathan Cortez, The Statutory Case Against OffLabel Promotion, 83 U. CHI. L. REV. ONLINE 124, 126 (2016) (arguing that "the FDCA as a whole depends on the ban" on off-label promotion); Christopher Robertson \& Aaron S. Kesselheim, Regulating Off-Label Promotion-A Critical Test, 375 New Eng. J. MED. 2313, 2315 (2016) ("We fear that these developments could be the beginning of an FDA retreat from the FDCA's fundamental precepts ...."); Sharfstein \& Charo, supra note 8, at 1795 (arguing that one company's off-label promotion lawsuit "challenged the US approach to drug regulation").

${ }^{21}$ United States v. Caronia, 703 F.3d 149, 179 (2d Cir. 2012) (Livingston, J., dissenting); see also Cortez, supra note 20, at 140 ("Moreover, if the FDA knew that once a drug was approved, it could be legally marketed for any use, the agency might weigh the benefits and risks less charitably in the first instance."). As discussed in more detail in infra Part IV.A.2, the FDCA requires the FDA, in its approval decisions, to assess whether a "drug is safe for use under the conditions prescribed, recommended, or suggested in the proposed labeling." 21 U.S.C. § 355(d) (2012). Based on this language, therefore, one might argue that the FDA cannot consider the risks of off-label uses in its approval decisions. When looking at the FDCA as a whole, however, there is also a case to be made that Congress did not intend to so limit the FDA. This statutory interpretation question is discussed in more detail in infra Part IV.A.2. 
The FDA, similar to other modern regulators, often relies on what scholars have called "information regulation"- "lighter-touch" regulatory tools, such as required disclosures or restrictions on marketing, that encourage the desired behavior or outcome, rather than directly mandating it through "command-andcontrol" tactics. ${ }^{22}$ But if stripped of the ability to oversee off-label drug promotion, the FDA could begin to more strictly regulate the drugs themselves or industry's nonexpressive conduct, to satisfy its statutory obligations to ensure that a drug's benefits outweigh its risks. Moreover, this shift closer to commandand-control regulation may not be limited to decisions about drugs. Instead, such a shift could extend to any FDA decision-making that relies on a benefit-risk assessment. ${ }^{23}$ This Article, therefore, examines potential indirect regulatory consequences of broader product promotion for the FDA's drug regulatory scheme, and also begins to explore the consequences for other areas in which FDA regulation relies on risk-benefit balancing, using new tobacco products as the example through which to undertake this analysis.

The FDA's authority to regulate new tobacco products is not the only area, other than new drugs, in which expanded protections for product promotion may indirectly affect the FDA's regulatory decisions. ${ }^{24}$ Most clearly, expanded protections for postapproval promotion also may affect the FDA's regulation of devices - products for which FDA policies also prohibit off-label promotion,

22 See, e.g., Amanda Shanor, The New Lochner, 2016 WIS. L. REV. 133, 163-64 (2016).

${ }^{23}$ For some products that the FDA oversees, it does not employ a risk-benefit assessment similar to that applied to drugs. For example, the FDA does not generally assess the "benefits" of foods and cosmetics - instead, its mission is to help ensure that foods and cosmetics are safe and properly labeled. See, e.g., CFSAN—What We Do, U.S. FOOD \& DRUG ADMIN., https://www.fda.gov/aboutfda/centersoffices/officeoffoods/cfsan/whatwedo/ [https://perma.cc/ASR6-U7DU] (last updated Aug. 18, 2016).

${ }^{24}$ It is also worth noting that, although the FDA is the focus of this Article, it is not the only regulator to consider. In particular, states have recently shown interest in regulating drugs in ways that challenge the FDA's policies. See, e.g., Lars Noah, State Affronts to Federal Primacy in the Licensure of Pharmaceutical Products, 2016 MICH. ST. L. REV. 1, 3 (2016); Patricia J. Zettler, Pharmaceutical Federalism, 92 IND. L.J. 845, 847-49 (2017). Offlabel promotion seems ripe to attract the attention of the states. For example, in 2017 Arizona enacted a law intended to permit truthful off-label promotion of drugs and devices. See H.R. 2382, 53d Leg., 1st Reg. Sess., sec. 1, § 32-1997(A) (Ariz. 2017). Although Arizona's law demonstrates that it is interested in enacting policies more permissive than the FDA's, other states may be interested in regulating drugs, or drug promotion, more strictly if the FDA were to play a diminished role in overseeing drug promotion. Indeed, as one example, states have brought lawsuits against opioid manufacturers accusing the companies of engaging in fraudulent marketing that downplayed the risks of the drugs and contributed to the opioid epidemic. See, e.g., Colin Dwyer, Ohio Sues 5 Major Drug Companies for 'Fueling Opioid Epidemic,' NPR (May 31, 2017), http://www.npr.org/sections/thetwoway/2017/05/31/530929307/ohio-sues-5-major-drug-companies-for-fueling-opioidepidemic [https://perma.cc/8585-T8G9]; see also Zettler, supra, at 848 (providing examples of state efforts to regulate drugs both more stringently and more leniently than the FDA does). Thus, just as expanded protections for off-label promotion may have indirect consequences for FDA regulation, such protections may likewise have indirect effects on the ways that states choose to regulate drugs. 
and for which premarket authorization generally is based on a product's safety and effectiveness. ${ }^{25}$ But this Article considers the example of the agency's new tobacco product authority to begin to examine how the indirect effects of increased protections for product promotion may extend beyond the context of medical products. ${ }^{26}$

Ultimately, this Article suggests that, because the FDA regulatory regime is a complex, interconnected one, limiting or eliminating FDA oversight of certain aspects of product promotion could alter other regulatory decisions, at least at the margins. ${ }^{27}$ Restricting off-label (and other kinds of) product promotion is a tool that the agency uses to manage the risks of what are often dangerous products. ${ }^{28}$ Eliminating that tool from the agency's repertoire could push the FDA to look to other - frequently more paternalistic — options, such as product gatekeeping or restrictions on product use, to achieve its public health mission. This result, in turn, may mean more restrictions on how providers prescribe and dispense drugs, and fewer approvals for new drug and new tobacco productsneither of which is likely to be a desirable outcome. There is, thus, yet another reason for stakeholders to be concerned that loosening the FDA's oversight of product promotion will result in unwanted consequences.

To establish the context for these regulatory consequences, Part II provides an account of recent controversies regarding the off-label promotion of prescription drugs. Part III considers the reach of recent court decisions protecting off-label promotion, and argues that one possible outcome, at least in the foreseeable future, is that courts will conclude that the First Amendment protects a broader scope of off-label promotion of approved drugs than the FDA has historically permitted. Part IV then delves into the ways that the FDA's regulatory regime for drugs may be affected by such expanded protection for off-label promotion in two specific areas-agency decisions about whether and how to limit the use of new drugs in medical practice, and new drug approvals. Part IV also begins to consider how greater protection for product promotion may affect the FDA's regulation of other products for which it weighs risks and benefits, such as new tobacco products.

\section{ThE OfF-LABEL Promotion CONTROVERSY}

To set the stage for considering the potential impact of expanded protections for the promotion of FDA-regulated products, this Part explains FDA policies on off-label promotion of drugs, and recent challenges to those policies.

${ }^{25}$ See, e.g., FDA MEMO, supra note 17, at 6-7 (describing the FDA's policies on offlabel promotion of devices).

${ }^{26}$ Infra Part IV.B.

27 Infra Parts IV and V.

${ }^{28} C f$. FDA MEMO, supra note 17, at 2-3 (explaining that " $[\mathrm{t}]$ he separate weighing of benefit and risk for each intended use is critical" because evidence supporting safety and effectiveness in one context does not necessarily support safety and effectiveness of the same product in another context). 


\section{A. The FDA's Position on Off-Label Promotion}

The FDA has broad authority over drugs sold in the United States. Under the FDCA, whether a product meets the definition of a drug such that it is subject to the FDA's requirements for drugs largely depends on the product's "intended uses." ${ }^{" 29}$ Specifically, a product is a drug if it is "intended for use in the diagnosis, cure, mitigation, treatment, or prevention of disease," or "intended to affect the structure or any function of the body." 30 Thus, the same substance may be a drug in some circumstances but not in others. For example, the FDA has explained "charcoal is the key ingredient in common products sold as fuel, a use outside FDA's jurisdiction, but charcoal products are drugs when intended for emergency treatment of poisoning." 31 And often the best piece of evidence demonstrating a product's intended use - at least for the purpose of determining whether a product meets the definition of a drug-is the manufacturer's representations about the product. ${ }^{32}$

If a product is determined to be a drug, it is subject to the FDA's many requirements for drugs, including the agency's premarket approval authority for new drugs. New drugs cannot be sold in the United States without the FDA's approval. ${ }^{33}$ When the FDA approves a drug, it approves that drug for the particular uses recommended in the drug's FDA-approved labeling. That is, the FDA approves a drug to treat a particular disease (or a particular stage of a disease), in a particular patient population, at a particular dose, and in a particular dosage form-all of which is reflected in the FDA-approved labeling. ${ }^{34}$ However, once the drug is approved, medical practitioners generally may prescribe the drug for any purpose, including uses not in the drug's FDAapproved labeling. ${ }^{35}$ These uses are described as "off-label."

${ }^{29} 21$ U.S.C. $\S 321(\mathrm{~g})(1)(2012) ; 21$ C.F.R. $\S 201.128$ (2016). To be subject to the FDA's jurisdiction, the drug (or its components) must also move in interstate commerce. See 21 U.S.C. $\$ \S 321(\mathrm{~g})(1), 331$.

3021 U.S.C. $\$ 321(\mathrm{~g})(1)(\mathrm{B})-(\mathrm{C})$. But not all products that are intended to affect the body's structure or function are medical products. For example, dietary supplements and conventional foods may be intended to affect the structure or function of the body in certain circumstances. See, e.g., Structure/Function Claims, U.S. FoOD \& DRUG ADMIN., https://www.fda.gov/food/ingredientspackaginglabeling/labelingnutrition/ ucm2006881.htm\#conventional [https://perma.cc/J86F-GH64] (last updated Aug. 2, 2017).

${ }^{31}$ FDA MEMO, supra note 17 , at 2 .

${ }^{32}$ See, e.g., 21 C.F.R. § 201.128; see also Lewis A. Grossman, Food, Drugs, and Droods: A Historical Consideration of Definitions and Categories in American Food and Drug Law, 93 CORNELl L. REV. 1091, 1108 (2008) ("Regulated industries contend that intended use is established solely by representations made in labeling, advertising, and other promotion. Conversely, the FDA maintains that it can look to the overall circumstances of distribution, foreseeable use [and] actual use ... to determine a product's intended use." (footnote omitted)).

3321 U.S.C. $\$ 355(a)$.

${ }^{34}$ See, e.g., Dresser \& Frader, supra note 17, at 477.

35 See, e.g., DANIEL CARPENTER, REPUTATION AND Power: ORganizational IMAge and Pharmaceutical Regulation at the FDA 617 (2010); Patricia J. Zettler, Toward 
Although practitioners are typically free to prescribe approved drugs offlabel, it has long been the FDA's position that a drug manufacturer's promotion of unapproved, off-label uses results in violations of the FDCA. ${ }^{36}$ The FDCA does not expressly prohibit off-label promotion. ${ }^{37}$ But the FDA interprets various FDCA provisions and the agency's implementing regulations such that off-label promotion is evidence that a drug is misbranded, and, in some cases, unapproved. ${ }^{38}$ The FDCA prohibits marketing in interstate commerce misbranded or unapproved drugs, and both criminal and civil penalties are available to the government if a drug manufacturer violates those prohibitions. ${ }^{39}$

One statutory rationale for the FDA's position, in short, is that under the FDCA and FDA regulations, if the intended use of an approved drug - as evidenced by the drug's labeling - is an unapproved use, the drug may be an unapproved new drug with respect to that off-label use. ${ }^{40}$ Even though the FDA approves certain pieces of a drug's labeling, off-label promotion can be found in a drug's labeling because "labeling," as defined in the FDCA and FDA regulations, is a broad category. ${ }^{41}$ It includes both the labeling that the FDA approves at the time a drug is approved, as well as many written, printed, or graphic promotional materials that the FDA does not approve before dissemination, including in some cases websites. ${ }^{42}$

Additionally, and more commonly, off-label promotion may be evidence that a drug is misbranded in violation of the FDCA. False or misleading offlabel promotion in labeling or advertising misbrands a drug. ${ }^{43}$ The FDCA also deems a drug to be misbranded if any of its labeling lacks "adequate directions" for all intended uses. ${ }^{44}$ Drugs promoted for off-label uses, including through oral statements, lack such adequate directions for the unapproved use by definition, because their FDA-approved labeling will not include directions for the unapproved use. ${ }^{45}$ Therefore, although off-label promotion itself is not expressly prohibited, in the FDA's view such promotion is evidence that drug manufacturers have violated the FDCA.

Coherent Federal Oversight of Medicine, 52 SAN DIEGo L. REV. 427, 436 n.45 (2015). For a discussion of some contexts in which medical practitioners may not prescribe drugs for off-label uses, see infra notes 160-61 and accompanying text.

${ }^{36}$ See, e.g., Cortez, supra note 20, at 124.

${ }^{37}$ See, e.g., United States v. Caronia, 703 F.3d 149, 154 (2d Cir. 2012).

${ }^{38}$ For a detailed description of the statutory support for the FDA's position, see Cortez, supra note 20, at 126.

3921 U.S.C. $\S \S 331(a), 331(d), 333(a)$ (2012).

${ }^{40} I d . \S \S 321(\mathrm{p}), 355(\mathrm{a}) ; 21$ C.F.R. $\S \S 201.128,310.3(\mathrm{~h})(4)$ (2016).

${ }^{41}$ See 21 U.S.C. $§ 321(\mathrm{~m})$; Kordel v. United States, 335 U.S. 345, 350 (1948); 21

C.F.R. $\S 202.1(l)(1991)$.

42 See 21 U.S.C. $\$ 321(\mathrm{~m}) ;$ Kordel, 335 U.S. at 350; 21 C.F.R. $\S 202.1(l)$.

4321 U.S.C. $\S \S 321(n), 352(a),(n) ; 21$ C.F.R. $\S 202.1(\mathrm{e})(5)(\mathrm{i}),(\mathrm{e})(6)(\mathrm{i})$.

4421 U.S.C. $\$ 352(f)(1)$.

${ }^{45}$ Id.; 21 C.F.R. $\S \S 201.5,201.100(\mathrm{c})(1)(2016)$. 


\section{B. Challenges to the FDA's Position}

As courts have expanded protections for commercial speech in general, ${ }^{46}$ industry and other stakeholders have used those protections to challenge the FDA's position on off-label promotion. ${ }^{47}$ This Part sets out the commercial speech doctrine that underlies challenges to the FDA's policies on off-label promotion, and explains how the courts have applied that doctrine to the FDA's policies in recent years.

\section{Protections for Commercial Speech}

Scholars point to the 1970 s as the beginning of the Supreme Court's recognition that commercial speech is protected under the First Amendment. ${ }^{48}$ As the Court explained in 1975 in Bigelow v. Virginia, "[a]dvertising is not... stripped of all First Amendment protection" because speech that is related to "the marketplace of products or of services" is not "valueless in the marketplace of ideas." 49 But the Court has also recognized that the First

${ }^{46}$ See, e.g., Va. State Bd. of Pharmacy v. Va. Citizens Consumer Council, 425 U.S. 748, 762 (1976); see also Jane R. Bambauer \& Derek E. Bambauer, Information Libertarianism, 105 CAL. L. REV. 335, 352-54 (2017) (describing the debate about expanding protections for commercial speech); Kenneth D. Katkin, First Amendment Lochnerism? Emerging Constitutional Limitations on Government Regulation of NonSpeech Economic Activity, 33 N. KY. L. REV. 365, 369 (2006) (describing the deregulatory effect of expanding protections for commercial speech); Jeremy K. Kessler, The Early Years of First Amendment Lochnerism, 116 CoLUM. L. REV. 1915, 1917, 1925 (2016) (discussing "the discourse of 'First Amendment Lochnerism"'); Shanor, supra note 22, at 135 (explaining that recent "trends have brought the First Amendment into greater conflict with the modern administrative state"); Rebecca Tushnet, Cool Story: Country of Origin Labeling and the First Amendment, 70 FoOD \& DRUG L.J. 25, 26 (2015) (describing First Amendment Lochernism in the context of required country of origin labeling for meat).

${ }^{47}$ In determining whether speech is "commercial," courts generally consider whether the speech is advertising, whether it discusses a specific product, and whether the speaker has economic motivations. See, e.g., Bolger v. Youngs Drug Prods. Corp., 463 U.S. 60, 6667 (1983). Put more succinctly, courts examine whether the speech is "solely related to the economic interests of the speaker and its audience." United States v. Caronia, 703 F.3d 149, 163 (2d Cir. 2012). As Nathan Cortez has explored, in some circumstances it may be possible for speech by FDA-regulated industry to be noncommercial, and thus entitled to heightened protection. Nathan Cortez, Can Speech by FDA-Regulated Firms Ever Be Noncommercial?, 37 AM. J.L. \& MED. 388, 390 (2011); see also Jennifer L. Herbst, Off-Label "Promotion" May Not Be Merely Commercial Speech, 88 TEMP. L. REV. 43, 73-74 (2015); Joseph Leghorn et al., The First Amendment and FDA Restrictions on Off-Label Uses: The Call for a New Approach, 63 FOOD \& DRUG L.J. 391, 397 (2008). This Article, however, presumes that courts will consider off-label promotion to be commercial speech both because that is what courts have done, and because the circumstances in which a drug manufacturer's speech might be noncommercial are likely to be limited. See, e.g., Caronia, 703 F.3d at 163; Wash. Legal Found. v. Henney, 202 F.3d 331, 334 (D.C. Cir. 2000); Cortez, supra, at 390.

48 See, e.g., Kesselheim \& Mello, supra note 16, at 1550.

${ }^{49}$ Bigelow v. Virginia, 421 U.S. 809, 826 (1975). 
Amendment "impos[es] looser constraints when the government seeks to restrict ... commercial speech" than when it seeks to restrict noncommercial speech. ${ }^{50}$ That is, government restrictions on commercial speech are often described as subject to "intermediate scrutiny." 51

In the 1980 case Central Hudson Gas \& Electric Corp. v. Public Service Commission of New York, the Supreme Court articulated a four-part test for determining whether a commercial speech regulation survives this intermediate scrutiny. ${ }^{52}$ First, if the regulated speech is false or misleading, or about unlawful activity, it does not qualify for protection. ${ }^{53}$ If, however, "the communication is neither misleading nor related to unlawful activity," the government restriction survives judicial review only if the government has a substantial interest at stake, the government's speech restriction directly advances that substantial interest, and the government's restriction is no more extensive than necessary. ${ }^{54}$

Although described as intermediate scrutiny, Central Hudson may be an increasingly difficult test for the government to satisfy. When courts consider mandated disclosures or government counter speech to be viable alternatives to directly restricting commercial speech, the government will face difficulty satisfying the fourth prong of the Central Hudson test - that the government's regulation be no more extensive than necessary. ${ }^{55}$ Moreover, some commercial speech restrictions may be subject to even more exacting scrutiny than the Central Hudson test establishes. In Sorrell v. IMS Health, Inc., decided in 2011, the Supreme Court explained that commercial speech restrictions that are "content-based"-meaning the government chooses to regulate the speech "because of disagreement with the message it conveys"-are subject to "heightened scrutiny." 56 The Court did not further explain what such "heightened scrutiny" entails, beyond explaining that the government must at least show that it satisfies the Central Hudson test. ${ }^{57}$ Government restrictions on commercial speech that is not false or misleading (or about an illegal product), thus, may face skeptical courts, whether those courts apply the intermediate scrutiny test from Central Hudson or the "heightened scrutiny" envisioned in Sorrell. 58

\footnotetext{
${ }^{50}$ Sorrell v. IMS Health Inc., 564 U.S. 552, 582 (2011) (Breyer, J., dissenting).

51 See, e.g., Caronia, 703 F.3d at 163; Berman, supra note 19, at 541.

52 Cent. Hudson Gas \& Elec. Corp. v. Pub. Serv. Comm'n, 447 U.S. 557, 566 (1980).

${ }^{53} \mathrm{Id}$. at $563-64$.

${ }^{54} \mathrm{Id}$. at 564 .

55 See, e.g., Berman, supra note 19 , at 508-09.

56 Sorrell v. IMS Health Inc., 564 U.S. 552, 565-66 (2011).

${ }^{57} \mathrm{Id}$. at 572.

${ }^{58}$ See, e.g., Berman, supra note 19, at 508 ("In the years following Central Hudson, the test has begun to look more like strict scrutiny ....").
} 


\section{Recent Applications to the FDA's Position}

Since first recognizing that the First Amendment protects commercial speech in the 1970s, the Supreme Court and lower courts have considered commercial speech protections for various types of prescription drug marketing, and stakeholders have had success challenging some legal restrictions on drug promotion. Some of these successes have come in the context of off-label promotion specifically, as when a federal judge concluded that the FDA's conditions under which drug manufacturers could distribute peer-reviewed and reference literature on off-label uses violated manufacturers' First Amendment rights. ${ }^{59}$ And others have come in the context of drug advertising more generally, as when the Supreme Court concluded in Sorrell v. IMS Health, Inc. that a Vermont law restricting the use of prescriber-identifying information for drug marketing "[was] contrary to basic First Amendment principles." 60

Yet, until recently, these cases did not seem to seriously challenge the FDA's position that off-label promotion leads to violations of the FDCA. Indeed, the government continued to successfully bring enforcement actions against companies and executives engaged in off-label promotion, often obtaining enormous payouts as part of settlements. For example, in 2009, Eli Lilly paid approximately $\$ 1.4$ billion to settle a case involving off-label promotion of its antipsychotic drug, Zyprexa, as a treatment for dementia. ${ }^{61}$ This promotion resulted not only in a violation of the FDCA - at least in the government's view-but also involved serious public health concerns. In addition to being unproven to be effective for dementia, Zyprexa is associated with an increased risk of death when used in elderly patients with dementiarelated psychosis. ${ }^{62}$

The landscape for the FDA to enforce its position on off-label promotion, however, seems to be changing. Scholars have argued that First Amendment jurisprudence is increasingly coming into conflict with the modern regulators' reliance on information regulation rather than command-and-control tactics. ${ }^{63}$ Consistent with this trend, in recent years the FDA has faced challenges to its position on off-label promotion on several occasions.

In 2009, the FDA faced a lawsuit that broadly challenged the agency's de facto ban on off-label promotion. The complaint, filed by Allergan, sought a decision permitting the company to distribute truthful and non-misleading

${ }^{59}$ Wash. Legal Found. v. Friedman, 13 F. Supp. 2d 51, 51-52 (D.D.C. 1998), appeal dismissed sub nom. Wash. Legal Found. v. Henney, 202 F.3d 331, 332 (D.C. Cir. 2000).

60 Sorrell, 564 U.S. at 576; see also Thompson v. W. States Med. Ctr., 535 U.S. 357, 373 (2002).

${ }^{61}$ U.S. Dep't of Justice, supra note 9.

${ }^{62}$ U.S. Food \& Drug Admin., supra note 12 (Zyprexa Labeling).

${ }^{63}$ See, e.g., Shanor, supra note 22, at 134-35; cf. Elizabeth Sepper, Free Exercise Lochnerism, 115 ColuM. L. REV. 1453, 1455 (2015) (making a similar argument with respect to the Religious Freedom Restoration Act and the free exercise clause of the First Amendment). 
information about the use of Botox for common off-label indications such as juvenile cerebral palsy and headaches. ${ }^{64}$ Notably, regulators in other countries had already approved Botox for treating juvenile cerebral palsy, ${ }^{65}$ and since the lawsuit, the FDA has approved Botox for chronic migraines. ${ }^{66}$ The government, however, settled with Allergan in 201067 - thereby avoiding the First Amendment question.

A few years later, the FDA was not as fortunate. In 2009, a jury found Alfred Caronia, a sales representative for a subsidiary of Jazz Pharmaceuticals (Jazz), guilty of a misdemeanor conspiracy to introduce misbranded drugs into interstate commerce based on Mr. Caronia's off-label promotion of Jazz's narcolepsy drug, Xyrem. ${ }^{68}$ The facts of the case, in some respects, seemed sympathetic to the FDA's position. According to the Second Circuit, Mr. Caronia "plainly promoted the use of Xyrem" for "unapproved uses," ranging from insomnia to fibromyalgia to Parkinson's disease..$^{69}$ Moreover, despite the serious risks associated with Xyrem, including death - for which the FDA had required a black box warning and a special risk mitigation program for the drug-Mr. Caronia asserted that Xyrem is "a very safe drug."

Nevertheless, in 2012 a two-judge majority of the Second Circuit overturned Mr. Caronia's conviction on First Amendment grounds. As a preliminary matter, despite the FDA's usual position that off-label promotion is evidence of a violation of the FDCA rather than a violation in and of itself, ${ }^{71}$ the majority determined that Mr. Caronia was prosecuted for his speech alone. ${ }^{72}$ The majority did not consider Mr. Caronia's speech to be evidence of the drug's intended use because the government's argument at trial suggested that "Caronia's speech was itself the proscribed conduct." 73

The majority then considered the appropriate standard for review. As in Sorrell, in which the Supreme Court concluded that Vermont's restrictions on using prescriber-identifying information for drug marketing were content based

${ }^{64}$ Complaint at 15, Allergan, Inc. v. United States, No. 1:09-cv-01879 (D.D.C. Oct. 1, 2009).

${ }^{65}$ See, e.g., Lise T. Spacapan \& Jill M. Hutchison, Prosecutions of Pharmaceutical Companies for Off-Label Marketing: Fueled by Government's Desire To Modify Corporate Conduct or Pursuit of a Lucrative Revenue Stream?, 22 AnNALs HeAlth L. 407, 429 (2013).

66 See, e.g., U.S. Food \& Drug Admin., Approved Labeling for Botox (Apr. 2017), https://www.accessdata.fda.gov/drugsatfda_docs/label/2017/103000s5302lbl.pdf [https://perma.cc/U2R5-PMAU].

${ }^{67}$ Press Release, U.S. Dep't of Justice, Allergan Agrees To Plead Guilty and Pay $\$ 600$ Million To Resolve Allegations of Off-Label Promotion of Botox (Sept. 1, 2010), https://www.justice.gov/opa/pr/allergan-agrees-plead-guilty-and-pay-600-million-resolveallegations-label-promotion-botox [https://perma.cc/HVM6-JFEN].

68 United States v. Caronia, 703 F.3d 149, 158-59 (2d Cir. 2012).

${ }^{69} \mathrm{Id}$. at 156.

${ }^{70} \mathrm{Id}$. at 157.

${ }^{71}$ See supra Part III.A.

${ }^{72}$ Caronia, 703 F.3d at $161-62$.

${ }^{73} \mathrm{Id}$. at 161 . 
and thus subject to "heightened scrutiny," the majority concluded that heightened scrutiny was warranted for Mr. Caronia's prosecution. ${ }^{74}$ But the majority nevertheless applied the four-part test from Central Hudson because if a government action cannot survive intermediate scrutiny under Central Hudson, it also cannot survive heightened scrutiny.

Because the government failed to argue that Mr. Caronia's statements were false or misleading at trial, the majority presumed that his statements were truthful and non-misleading, and focused on the last three factors of the Central Hudson test. ${ }^{75}$ Although the majority concluded that the government had a substantial interest in protecting the public's safety and health, it determined that prosecuting Mr. Caronia did not directly advance that interest because offlabel prescribing is generally permitted, and, thus, restricting information about such prescribing in fact might be detrimental to the public health. Moreover, the court identified a number of "less-speech restrictive" regulatory options available to the government, including distributing its own views about off-label uses, or even prohibiting off-label use itself. ${ }^{76}$ Accordingly the majority concluded that even if Central Hudson's "less rigorous intermediate test" applied to the government's action, prosecuting Mr. Caronia for his off-label speech violated his First Amendment rights. ${ }^{77}$

\section{CARONIA'S IMPACT}

It is, perhaps, an understatement to say that public health and FDA law scholars have identified Caronia as an important ruling. ${ }^{78}$ But roughly five years later, the decision's impact on FDA oversight is not entirely clear in part because the government declined to appeal the decision. ${ }^{79}$ In the absence of a Supreme

${ }^{74} I d$. at $163-64$.

${ }^{75} \mathrm{Id}$. at $166 \mathrm{n} .10$. There was, however, a strong argument that at least some of $\mathrm{Mr}$. Caronia's statements were false or misleading, and therefore not protected under the First Amendment. For example, Mr. Caronia described Xyrem as a "very safe drug." Id. at 157. But Xyrem is associated with serious risks, including the risk of death, and is a Schedule III controlled substance that presents a risk of misuse. Id. at 155. Additionally, its sodium salt is gamma hydroxybutyrate, or GHB, a Schedule I controlled substance often associated with use in sexual assaults. U.S. Food \& Drug Admin., Approved Labeling for Xyrem (Jan. 2017), https://www.accessdata.fda.gov/drugsatfda_docs/label/2017/021196s027lbl.pdf [https://perma.cc/M77W-4YLM].

${ }^{76}$ Caronia, 703 F.3d at 167.

${ }^{77} \mathrm{Id}$. at 164 .

${ }^{78}$ See, e.g., Aaron S. Kesselheim et al., FDA Regulation of Off-Label Drug Promotion Under Attack, 309 JAMA 445, 445 (2013); Wendy Parmet \& Peter D. Jacobson, The Courts and Public Health: Caught in a Pincer Movement, 104 AM. J. PuB. HEALth 392, 393 (2014); Sharfstein \& Charo, supra note 8, at 1795.

${ }^{79} C f$. Letter from Richard A. Samp, Chief Counsel, \& Mark S. Chenoweth, General Counsel, Wash. Legal Found., to Food \& Drug Administration 9 (May 19, 2017), http://wlf.org/upload/litigation/briefs/FDAComments-IntendedUse.pdf [https://perma.cc/5643ZTTN] (noting that "FDA questions the continued vitality of Caronia ... [b]ut ... if it disagreed with the Second Circuit's legal analysis, it should have sought review of the 
Court opinion, stakeholders and commentators have debated and scrutinized Caronia's effect on the FDA's ability to regulate product promotion. Three possible views of Caronia's impact have emerged.

\section{A. It Changes Nothing}

One possibility is that Caronia will not lead to meaningful changes in the FDA's regulation of advertising and promotion. Shortly after Caronia was decided, the director of the FDA's Office of Prescription Drug Promotion (OPDP) explained that Caronia would not "significantly affect" the agency's off-label promotion policies because the decision did not address the constitutionality of using off-label promotion as evidence of intended use, nor did it strike down any provisions of the FDCA or FDA regulations. ${ }^{80}$

In 2016, in United States ex rel. Polansky v. Pfizer, the Second Circuit seemed to partly endorse the OPDP director's view of the Caronia decision, albeit in dictum. ${ }^{81}$ Polansky was a False Claims Act case that focused on the questions of whether a manufacturer engaged in off-label marketing, and, through that marketing, improperly induced federal and state health care programs to pay for the drug. ${ }^{82}$ The allegedly off-label promotion involved marketing Lipitor, a drug that the FDA approved for lowering cholesterol, for that use but for a purportedly inappropriate patient population. The court ultimately concluded that Lipitor had not been marketed off-label, but also noted in a footnote that "Caronia left open the government's ability to prove misbranding on a theory that promotional speech provides evidence that a drug is intended for a use that is not included on the drug's FDA-approved label." 83

Consistent with this view, in January 2017 the FDA published a lengthy memorandum documenting its public health rationale for its policies on offlabel promotion as well as various arguments that those policies comport with the First Amendment. ${ }^{84}$ Among other things, the memorandum asserted that the First Amendment does not prohibit the use of product promotion as evidence of intended use. ${ }^{85}$ The agency cited Polansky, as well as numerous other cases in which courts have reached the conclusion that product promotion may be used

panel's decision"); Stephanie M. Greene \& Lars Noah, Off-Label Drug Promotion and the First Amendment, 162 U. PA. L. REV. ONLINE 239, 248 (2014) (in which Lars Noah notes that the government's decision not to appeal may have reflected concerns "that the Supreme Court might take the occasion to put another nail in the coffin of FDA speech regulation").

80 Jill Wechsler, Tom Abrams: Caronia Won't Stop Off-Label Enforcement, PHARMEXEC.COM (Jan. 29, 2013), http://www.pharmexec.com/tom-abrams-caronia-wontstop-label-enforcement [https://perma.cc/8CJV-FCPA]. As OPDP's name suggests, it is the office within the FDA responsible for overseeing prescription drug advertising and promotion.

${ }^{81}$ United States ex rel. Polansky v. Pfizer, 822 F.3d 613, 615 n.2 (2d Cir. 2016).

${ }^{82} \mathrm{Id}$. at 614 .

${ }^{83} \mathrm{Id}$. at $615 \mathrm{n} .2$ (emphasis added).

${ }^{84}$ See FDA MEMO, supra note 17 , at 3.

${ }^{85}$ See id. at 21-22. 
to determine whether a wholly unapproved product is a drug subject to relevant FDA requirements. ${ }^{86}$

Additionally, some courts outside of the Second Circuit have expressly declined to follow Caronia. For example, one judge in the Eastern District of California explained that the idea that off-label promotion is permissible "has gained little traction" in the Ninth Circuit. ${ }^{87}$ One also might (or might not) point to the fact that the FDA has yet to revise its drug promotion regulations, ${ }^{88}$ and the government's continued ability to settle at least some off-label promotion cases for large amounts, ${ }^{89}$ as evidence that Caronia has not meaningfully affected the FDA's authority in this area, nor will it in the future. ${ }^{90}$

${ }^{86}$ Id. at 21-25; see, e.g., Whitaker v. Thompson, 353 F.3d 947, 953 (D.C. Cir. 2004).

${ }^{87}$ Hawkins v. Medtronic, Inc., 62 F. Supp. 3d 1144, 1151 (E.D. Cal. 2014); see also Ramirez v. Medtronic Inc., 961 F. Supp. 2d 977, 990 (D. Ariz. 2013) (“Off-label promotion, then, violates federal law and may carry criminal penalties."); $c f$. Jones v. Medtronic, 89 F. Supp. 3d 1035, 1047 (D. Ariz. 2015) ("Courts differ as to whether 'off-label' promotion and use violates FDA requirements."). Just three months after the Second Circuit decided Caronia, in United States. v. Harkonen the Ninth Circuit upheld a criminal conviction that was based on statements that the former CEO of a drug company made about the results of a clinical trial of a new, unapproved use for the company's approved drug. United States v. Harkonen, 510 F. App'x 633, 636 (9th Cir. 2013). Harkonen is distinguishable from Caronia because the defendant was convicted of wire fraud - meaning that a jury found that his speech was false or misleading, and intentionally or knowingly so. See id.; United States v. Harkonen, No. C 08-00164 MHP, 2010 WL 2985257, at*1 (N.D. Cal. July 27, 2010); see also Stephanie M. Greene, After Caronia: First Amendment Concerns in Off-Label Promotion, 51 SAN DiEGo L. ReV. 645, 684-89 (2014) (describing Harkonen). Nevertheless, some have argued that Harkonen suggests that courts may find limits on the First Amendment protections announced in Caronia. See, e.g., Marcia M. Boumil \& Kaitlyn L. Dunn, Off-Label Marketing of Pharmaceutical Products in the Wake of United States v. Caronia and United States v. Harkonen, 9 J. HEALTH \& BIOMEDICAL L. 385, 430-31 (2014).

88 See, e.g., 21 C.F.R. § 202.1 (2017).

${ }^{89}$ See, e.g., Press Release, U.S. Dep't of Justice, supra note 10; $c f$. Isaac D. Buck, Side Effects: State Anti-Fraud Statutes, Off-Label Marketing, and the Solvable Challenge of Causation, 36 CARDOZO L. REV. 2129, 2132-33 (2015) (discussing state efforts to regulate off-label promotion through litigation under state consumer protection and fraud laws). There are, however, other important reasons that the federal government may have had continued success in settling off-label promotion cases. One is the government's ability to exclude individuals and entities convicted of certain criminal violations of the FDCA from participation in federal health care programs, such as Medicare. See 42 U.S.C. § 1320a-7 (2012); see also Friedman v. Sebelius, 686 F.3d 813, 817 (D.C. Cir. 2012) (describing the government's authority under 42 U.S.C. $§ 1320 \mathrm{a}-7)$. With such high stakes, companies and executives charged with violations stemming from off-label promotion may be inclined to settle regardless of the strength of the government's legal position, to avoid even a small chance of exclusion.

90 See Marc J. Scheineson \& Guillermo Cuevas, United States v. Caronia: The Increasing Strength of Commercial Free Speech and Potential New Emphasis on Classifying Off-Label Promotion as "False and Misleading," 68 FoOD \& DRUG L.J. 201, 211 (2013) ("When the dust settles from Caronia, the federal government may decide to not fundamentally change its compliance posture for off-label promotion."). 


\section{B. It Changes Everything}

A second possibility - and the one most concerning for many scholars and public health advocates - is that Caronia will be interpreted broadly such that it undermines the benefits of the FDA's premarket approval system, or wholly dismantles the system. ${ }^{91}$ Indeed, one high-ranking FDA official was reportedly "horrified" when the Second Circuit decided Caronia in 2012, possibly in recognition of the potential for the decision to broadly disrupt drug regulation..$^{92}$ As the FDA has explained, permitting broader off-label promotion may diminish industry incentives for studying and obtaining approval for new uses of drugs..$^{93}$ This result would be troubling because an important function of FDA regulation is to incentivize the production of scientific knowledge about medical products..$^{94}$

The fears that the entire drug approval system will be undermined stem from concerns that Caronia will be interpreted to significantly limit, or eliminate altogether, the FDA's ability to rely on off-label promotion as evidence of violations of the FDCA. As Robertson argues in his article in this Issue, such an interpretation of Caronia could extend to the promotion of unapproved drugs, including obviously ineffective and fraudulent products. ${ }^{95}$ That is, if courts extend Caronia to conclude that product promotion cannot be evidence of intended use in the postapproval context, courts logically could conclude that product promotion, likewise, cannot be evidence of intended use in the preapproval context. ${ }^{96}$ This would present a significant obstacle to the FDA regulation of drugs because often the FDA uses the manufacturer's speech to demonstrate that the product falls within the definition of a drug - meaning the product is intended to address disease or affect the structure or function of the body - and the government alleges that the manufacturer has violated the law by selling an unapproved new drug. ${ }^{97}$ Thus, if courts were to extend Caronia to

${ }^{91}$ See, e.g., Robertson, Tip of the Iceberg, supra note 20, at 1023-26.

92 Brenda Sandburg, Off-Label Ruling's Potential Fallout Is "Terrifying," FDA's Temple Says, THE PINK SHEET, Dec. 17, 2012, at 1.

93 Declaration of Janet Woodcock, M.D. at 94 4-6, Amarin Pharma, Inc. v. U.S. FDA, 119 F. Supp. 3d 196 (S.D.N.Y 2015) (No. 15 Civ. 3588); FDA MEMO, supra note 17, at 14; see also Wash. Legal Found. v. Friedman, 13 F. Supp. 2d 51, 69 (D.D.C. 1998) (describing "providing manufacturers with ample incentive to get previously unapproved uses on label" as one government interest in regulating off-label promotion).

${ }^{94}$ See, e.g., FDA MEMO, supra note 17, at 18; Eisenberg, Problem, supra note 17, at 719,725 .

${ }_{95}$ Robertson, Tip of the Iceberg, supra note 20, at 1040-44.

96 See id. at 1042; see also Cortez, supra note 20, at 140 (explaining that eliminating the prohibition on off-label use "would also draw into question not only the century-old intended use doctrine, but also the very definitions of 'drug' and 'device,' which also depend on intent").

${ }^{97}$ See, e.g., Whitaker v. Thompson, 353 F.3d 947, 948-49 (D.C. Cir. 2004); United States v. Cole, 84 F. Supp. 3d 1159, 1163 (D. Or. 2015). A drug's intended use is also critical 
the unapproved products context, the FDA may not be able to enforce requirements for premarket approval, essentially eliminating the FDA's gatekeeping role for drugs. ${ }^{98}$ And that result would also reach far beyond the FDA context, disrupting other regulatory regimes that rely on speech as evidence of intent. ${ }^{99}$

That said, none of the decisions following Caronia - in the Second Circuit or elsewhere - have extended Caronia to unapproved products. ${ }^{100}$ There may be practical reasons for this. As Robertson notes in his article, even if the logic of Caronia can extend quite far, "courts can and do draw arbitrary lines."101 Although the FDA frequently relies on speech as evidence in cases regarding wholly unapproved drugs, courts may be disinclined to extend Caronia's rationale to that context because it is expressly stated in the FDCA that selling unapproved new drugs is illegal. ${ }^{102}$ Given the explicit statutory prohibition, it may be easier for courts to agree with the FDA's argument that the agency is prohibiting the conduct of selling an unapproved drug - not the promotional speech - and is simply using the speech as evidence that the product is a new drug under the law. ${ }^{103}$ Although it is the FDA's position that selling approved drugs that have been promoted for off-label uses likewise is conduct that violates the FDCA - and there is a strong argument supporting the agency's

to demonstrating that the product is a "new drug" subject to the requirements for premarket approval. See Whitaker, 353 F.3d at 950.

${ }^{98}$ See Robertson, Tip of the Iceberg, supra note 20, at 1051-52.

${ }^{99}$ See id. at 1025.

100 See, e.g., id. at 1028-30.

${ }^{101} \mathrm{Id}$. at 1051.

10221 U.S.C. § 355(a) (2012); see also United States v. Caputo, 517 F.3d 935, 939 (7th Cir. 2008) (distinguishing off-label promotion and the sale of unapproved devices).

103 There are times when the government proceeds against the manufacturer of a wholly unapproved drug on the theory that the company is violating the law by selling a misbranded or adulterated, rather than an unapproved, drug. For example, the FDA has jurisdiction over a drug only when it (or its components) move in interstate commerce. 21 U.S.C. $\S \S 321(\mathrm{~g})$, 331. This limitation on the FDA's authority is rarely relevant because modern product production generally involves at least product components crossing state and international borders. But in a case that involved an unapproved autologous stem cell therapy, one issue was whether, and when, the product had traveled in interstate commerce such that the FDA had jurisdiction over it. See United States v. Regenerative Scis., LLC, 741 F.3d 1314, 1320 (D.C. Cir. 2014). The FDA has more flexibility in finding evidence of the needed nexus with interstate commerce for misbranded and adulterated drugs than it does for unapproved drugs. See 21 U.S.C. § 331(a), (c), (k). Thus, in the case of this unapproved stem cell therapy, the evidence supporting the government's allegations of misbranding and adulteration violations was likely stronger than the evidence that would have supported allegations of unapproved drug violations. And, in fact, the government's theory was that the stem cell therapy was misbranded and adulterated. See, e.g., Regenerative Scis., 741 F.3d at 1318. But even when the government proceeds against the manufacturer of a wholly unapproved new drug on a theory that the drug is misbranded or adulterated, courts have been willing to accept company statements as evidence of intended use, see, e.g., id.-perhaps because it is well-accepted that unapproved new drugs violate the law, even if the government's theory does not rely on a lack of approval. 
position ${ }^{104}$ - it is a much more nuanced statutory interpretation argument than a claim that selling wholly unapproved new drugs violates the law. Because of the complicated statutory interpretation underlying the FDA's position on off-label promotion, it may be more difficult for the government to persuade judges and juries that selling products that are promoted off-label is illegal conduct and offlabel promotion is being used solely as evidence as intent.

\section{It Changes Some Things}

Because courts, thus far, have declined to extend Caronia to the context of unapproved products, a third possibility, and perhaps the most likely scenario for the foreseeable future, is that Caronia will affect FDA oversight by broadening product promotion, but only for FDA-approved products. There are some practical signs that Caronia has made the FDA cautious in its regulation of prescription drug advertising and promotion without completely halting enforcement. For example, the FDA sent relatively few warning and untitled letters regarding prescription drug promotion in recent years - sending only 9 in $2014,{ }^{105} 9$ in 2015, ${ }^{106}$ and 11 in 2016, ${ }^{107}$ compared with 31 in 2011, ${ }^{108}$ the year before Caronia was decided, 51 in 2010, ${ }^{109}$ and 41 in 2009. ${ }^{110}$ Although there

104 See, e.g., Cortez, supra note 20, at 129.

105 Warning Letters 2014, U.S. FOOD \& DRUG ADMIN., http://wayback.archiveit.org/7993/20170111082153/http://www.fda.gov/Drugs/GuidanceComplianceRegulatoryI nformation/EnforcementActivitiesbyFDA/WarningLettersandNoticeofViolationLetterstoPh armaceuticalCompanies/ucm380323.htm\#DDMAC [https://perma.cc/W2YG-QDU2] (last updated July 9, 2016).

106 Warning Letters 2015, U.S. FoOD \& DRUG ADMIN., https://www.fda.gov/Drugs/ GuidanceComplianceRegulatoryInformation/EnforcementActivitiesbyFDA/WarningLetter sandNoticeofViolationLetterstoPharmaceuticalCompanies/ucm432949.htm [https://perma.cc/9BSZ-UW3X] (last updated Aug. 9, 2017).

107 Warning Letters 2016, U.S. FOOD \& DRUG ADMIN., https://www.fda.gov/Drugs/ GuidanceComplianceRegulatoryInformation/EnforcementActivitiesbyFDA/WarningLetter sandNoticeofViolationLetterstoPharmaceuticalCompanies/ucm482462.htm [https://perma.cc/NU3E-85YN] (last updated Aug. 9, 2017).

108 Warning Letters 2011, U.S. FOOD \& DRUG ADMIN., http://wayback.archive-it.org/ 7993/20170111082210/http://www.fda.gov/Drugs/GuidanceComplianceRegulatoryInform ation/EnforcementActivitiesbyFDA/WarningLettersandNoticeofViolationLetterstoPharmac euticalCompanies/ucm238583.htm [https://perma.cc/8WGX-QNL5] (last updated Mar. 14, 2016).

109 Warning Letters 2010, U.S. FOOD \& DRUG ADMIN., http://wayback.archive-it.org/ 7993/20170111082214/http://www.fda.gov/Drugs/GuidanceComplianceRegulatoryInform ation/EnforcementActivitiesbyFDA/WarningLettersandNoticeofViolationLetterstoPharmac euticalCompanies/ucm197224.htm [https://perma.cc/U2FQ-HSEN] (last updated Mar. 5, 2015) (letters sent from the Division of Drug Marketing, Advertising, and Communications).

110 Warning Letters 2009, U.S. FOOD \& DRUG ADMIN., http://wayback.archiveit.org/7993/20170111082216/http://www.fda.gov/Drugs/GuidanceComplianceRegulatoryI nformation/EnforcementActivitiesbyFDA/WarningLettersandNoticeofViolationLetterstoPh armaceuticalCompanies/ucm055773.htm [https://perma.cc/7N8N-EGN9] (last updated 
are many reasons why the FDA may have sent fewer letters in this area in the last several years, one possibility is that the FDA is currently exercising its enforcement powers conservatively to avoid First Amendment challenges. ${ }^{111}$

Additionally, the agency has made public that it is in the process of reexamining its off-label promotion policies. The FDA hosted a public meeting in November 2016 to obtain input on off-label promotion, ${ }^{112}$ at which commenters raised constitutional questions about the agency's policies. ${ }^{113}$ The agency then published a sixty-three page memo detailing its public health interests in regulating off-label promotion and its current view of the First Amendment caselaw to provide additional information for interested stakeholders and solicit more public input. ${ }^{114}$

Although it is not yet clear what result the agency's re-examination of its own policies will have, several cases that followed Caronia also suggest that the protections announced in Caronia may provide an avenue for broader promotion of approved products. In Amarin Pharma, Inc. v. FDA, a federal judge in the Southern District of New York (which, notably, is in the Second Circuit), relied on Caronia to enjoin the FDA from prohibiting Amarin from engaging in "truthful and non-misleading speech promoting the off-label use of [its drug] Vascepa."115 The FDA approved Vascepa in 2012 to reduce triglyceride levels in adults with severe hypertriglyceridemia, a risk factor for coronary artery disease. ${ }^{116}$ Amarin then sought FDA approval for use in a broader patient population-patients with triglyceride levels that were persistently high, but did not amount to severe hypertriglyceridemia. The FDA denied approval for the broader indication, and in its letter to the company, reminded Amarin that Vascepa "may be considered to be misbranded" under the FDCA if marketed for the sought-after, but still unapproved, indication. 117 Amarin then went to court to seek an injunction that would prevent the FDA from prohibiting the company from making "truthful and non-misleading" offlabel statements about Vascepa. ${ }^{118}$ Finding for Amarin, the federal judge concluded that the FDA may not bring an enforcement action based solely on truthful promotion about an approved drug. ${ }^{119}$ The FDA then settled with

Mar. 28, 2016) (letters sent from the Division of Drug Marketing, Advertising, and Communications).

${ }^{111}$ See, e.g., Patricia J. Zettler, Regulating Drug Promotion To Promote the Public Health: A Response to Bennett et al., 2 J.L. \& BIOSCIENCES 712, 714 (2015).

112 Public Hearing, 81 Fed. Reg. 60,299 (Sept. 1, 2016).

113 FDA MEMO, supra note 17, at 21.

114 John T. Aquino, Off-Label Drug Promotion Could Happen if Stakeholders Agree, Bloomberg BNA: Health CARE Blog (May 12, 2017), https://www.bna.com/offlabeldrug-promotion-b73014450900/ [https://perma.cc/T2WP-CM9Z].

115 Amarin Pharma, Inc. v. U.S. FDA, 119 F. Supp. 3d 196, 237 (S.D.N.Y. 2015).

116 Id. at 209.

117 See id. at 212.

118 Id. at $212,215$.

${ }^{119}$ Id. at 237. 
Amarin, agreeing, among other things, not to appeal the decision. ${ }^{120}$ Additionally, several months after the Amarin decision, the agency settled another off-label promotion lawsuit brought in New York by Pacira Pharmaceuticals, Inc. ${ }^{121}$

The FDA's decision to settle with Amarin and Pacira indicates that Caronia, in fact, is affecting FDA regulation of off-label promotion. These settlements suggest that the agency was not confident in its ability to prevail in further litigation, at least in the Second Circuit. But that Caronia is binding only in the Second Circuit does not necessarily significantly limit its impact. Amarin and Pacira demonstrate that, whenever the FDA threatens to enforce its de facto prohibition on off-label marketing, companies may elect to file a complaint seeking an injunction in a federal court in the Second Circuit, which will be bound by Caronia. ${ }^{122}$ Additionally, several district courts outside of the Second Circuit have followed Caronia's reasoning to conclude that truthful, nonmisleading off-label promotion about approved products is permissible, which suggests that Caronia may be persuasive in other jurisdictions. ${ }^{123}$ Accordingly, as a practical matter, Caronia - combined with Amarin, Pacira, and the other subsequent cases suggesting that Caronia was not a fluke-may substantively change the pharmaceutical industry's advertising and promotion strategies.

120 See, e.g., Eric Palmer, With FDA Settlement, Tiny Amarin Creates Opening for Pharma in Off-Label Marketing, FIERCEPHARMA (Mar. 9, 2016), http://www.fiercepharma .com/pharma/fda-settlement-tiny-amarin-creates-opening-for-pharma-off-label-marketing [https://perma.cc/ZDP3-EPXW].

${ }^{121}$ See, e.g., Alan Bennett et al., Affirming the Need for a New Model for the Regulation of Drug Promotion: A Rebuttal to Krause and Zettler, 3 J.L. \& BIOSCIENCES 192, 193 (2016), https://www.ncbi.nlm.nih.gov/pmc/articles/PMC5033428/ [https://perma.cc/WE72-M63Z].

122 See, e.g., Nicholas Bagley, Can FDA Tell a Drug Company To Stop Talking About Research?, INCIDENTAL ECONOMIST (Aug. 13, 2015), http://theincidentaleconomist.com/ wordpress/can-fda-tell-a-drug-company-to-stop-talking-about-research/ [https://perma.cc/ 4VN6-G2CR].

123 See, e.g., Dawson v. Medtronic, Inc., No. 3:13-cv-663-JFA, 2013 U.S. Dist. LEXIS 112877 , at *17 (D.S.C. Aug. 9, 2013) ("[F]or any of these claims to survive the instant motion to dismiss, the court must accept Plaintiff's premise that off-label promotion is illegal under the FDCA, and this court cannot do so."); see also United States v. Facteau, No. 1:15cr-10076, 2016 WL 4445741, at *2 n.1 (D. Mass. Aug. 22, 2016) (jury acquitting two medical device executives of felony fraud and FDCA violations based on off-label promotion); Final Jury Instruction at 12, United States v. Vascular Sols., Inc., 181 F. Supp. 3d 342 (W.D. Tex. 2016) (No. 5:14-CR-00926) (instructing the jury that off-label promotion of a device is "not illegal"); Robertson \& Kesselheim, supra note 20, at 2314 (discussing Facteau); David L. Rosen et al., How Will FDA Regulate Off-Label Communications in the Post-Facteau World?, Article in Food and Drug Policy Forum, FoOD \& DRUG L. INST. (Sept. 26, 2016), https://www.fdli.org/2016/09/will-fda-regulate-off-labelcommunications-post-facteau-world/ [https://perma.cc/JZ3U-4X4V] (discussing Vascular Solutions and Facteau). 
One might note that the circumstances of Caronia, Amarin, and Pacira (and Allergan) may have been unusually unfavorable for the FDA. ${ }^{124}$ As already noted, in Caronia the government failed to argue that the speech at issue was false or misleading. Amarin, likewise, involved unusual circumstances. ${ }^{125}$ The active ingredient in Vascepa is icosapent ethyl, which is an omega-3 fatty acid similar to an ingredient in fish oil products that are marketed as dietary supplements. ${ }^{126}$ Those supplements may be legally marketed to persons without severe hypertriglyceridemia, ${ }^{127}$ and the inconsistent treatment of the productseven though required by the differing regulatory regimes that Congress has established for drugs and dietary supplements - seemed not to sit well with the deciding judge. ${ }^{128}$ Pacira similarly involved a potentially uncommon situation in which one contested issue was what the label encompassed-meaning the dispute between the company and the agency focused in part on whether the promotion was on- or off-label. ${ }^{129}$

Amarin and Pacira also pre-dated the Second Circuit's Polansky opinion, in which the court commented that Caronia does not foreclose the possibility that the government could use off-label promotion as evidence of intended use needed to prove a violation of the FDCA. ${ }^{130}$ But in Polansky, the Second Circuit concluded that off-label promotion had not taken place-meaning it did not address the circumstances of Amarin and Pacira, nor did it decide the question of when off-label promotion may, or may not, be used as evidence of violations of the FDCA. ${ }^{131}$ Moreover, the Second Circuit seemed to endorse a definition of off-label promotion that may be narrower than the FDA's definition. ${ }^{132}$ The court identified a "distinction" between promoting a drug for diseases and conditions for which it is unapproved, and promoting a drug for its approved purpose but to populations "neither specified nor excluded in the label."133 The FDA may not draw a similar distinction. ${ }^{134}$ Thus, it is not clear how helpful

${ }^{124}$ In Allergan, as noted above, the company sought assurances that it could market Botox off-label for numerous indications including some that were either approved in other countries or ultimately approved by the FDA. Complaint at 16-17, Allergan, Inc., v. United States, No: 1.09-cv-01879 (D.D.C. filed Oct. 1, 2009).

125 Amarin Pharma, Inc. v. U.S. FDA, 119 F. Supp. 3d 196 (S.D.N.Y. 2015).

126 Id. at 209.

127 Id. at $228-29$.

128 See id.

${ }^{129}$ Complaint at 4-5, Pacira Pharms., Inc. v. U.S. FDA, No. 1:15-cv-0755 (S.D.N.Y. filed Sept. 8, 2015).

130 United States ex rel. Polansky v. Pfizer, Inc., 822 F.3d 613, 615 n.2 (2d Cir. 2016).

${ }^{131} I d$. at 620 .

$132 \mathrm{Id}$

$133 \mathrm{Id}$

134 The FDA's view is that promoting a drug for an unapproved patient population constitutes off-label promotion. See, e.g., Cortez, supra note 20, at 124 ("Off-label use can range from conspicuous (prescribing a product for an unapproved medical condition or patient group) to more subtle (prescribing beyond the approved dosage, duration, or any other parameter set forth in the approved labeling)."). But at issue in Polansky was whether 
Polansky would have been for the government, had it been decided before Amarin and Pacira. Taken together, Caronia and subsequent cases seem to have affected the extent to which the FDA can enforce its policies on off-label promotion, at least in certain circumstances, ${ }^{135}$ leading to the possibility for broader promotion of approved drugs than the FDA has historically permitted.

\section{EXPLORING INDIRECT CONSEQUENCES}

Even if protections for off-label promotion are limited to claims about approved products, we are likely to see broader prescription drug promotion than the FDA has historically tolerated. However courts define what constitutes "truthful and non-misleading" claims about approved prescription drugs, and however the FDA may revise its promotion policies, the result is likely to be one that permits a wider range of promotion. ${ }^{136}$ One question that Caronia, thus, raises is how broader drug promotion might change other areas of FDA regulation under its existing authority, particularly in ways that may not be as vulnerable to First Amendment challenges. ${ }^{137}$ And because First Amendment protections for drug promotion are likely to also apply to other products within the FDA's jurisdiction, this question is not limited to prescription drug regulation. Instead, such indirect effects might occur in any area in which the FDA weighs risks and benefits and in which broader product promotion can alter that balance of risks and benefits.

This Part takes up the question of what Caronia and its progeny's indirect effects may be, arguing that limiting the FDA's ability to regulate product promotion may increase the risks of the products and thus alter the way that the FDA implements its authorities that are linked to a weighing of risks and benefits. ${ }^{138}$ It first explores the possible indirect consequences of Caronia on

the drug, in fact, was promoted for an unapproved patient population, with the court ultimately concluding it was not so promoted. Polansky, 822 F.3d at 620 . Therefore, it is not entirely clear whether the court meant to define off-label promotion more narrowly than the FDA does.

${ }^{135}$ See, e.g., Amarin Pharma, Inc. v. U.S. FDA, 119 F. Supp. 3d 196, 226 (S.D.N.Y. 2015) (rejecting the FDA's interpretation of Caronia as "a mere artifact of that case's particular facts and circumstances").

136 See, e.g., Hey \& Kesselheim, supra note 19, at 1; see also Joan H. Krause, Truth, Falsity, and Fraud: Off-Label Drug Settlements and the Future of the Civil False Claims Act, 71 FOOD \& DRUG L.J. 401, 403 (2016) ("If pharmaceutical manufacturers are emboldened by Caronia to challenge [off-label] FCA prosecutions,... the resulting litigation is likely to focus on the truth or falsity of the company's statements ....").

${ }^{137}$ Cf. United States v. Caronia, 703 F.3d 149, 179 (2d Cir. 2012) (Livingston, J., dissenting).

${ }^{138}$ To be clear, this Part does not analyze a comprehensive list of potential regulatory consequences of broader product promotion. For example, this Part does not discuss device regulation in detail. As another example, the FDA might choose to require that product promotion include certain warnings. Such a requirement, however, would be compelled speech vulnerable to First Amendment challenges. See, e.g., Micah L. Berman, Clarifying Standards for Compelled Commercial Speech, 50 WASH. U. J.L. \& POL'Y 53, 54 (2016). As 
the regulation of new drugs, and specifically on the FDA's risk mitigation and approval authorities. This Part then begins to consider areas other than new drugs in which Caronia may also affect the FDA's decision-making, focusing on the FDA's approval authority for new tobacco products as an example of how Caronia's impact may extend even beyond the context of medical products.

\section{A. The FDA's Regulation of New Drugs}

This Part considers the consequences of expanded protection for off-label promotion for the FDA regulation of new prescription drugs, suggesting that it may lead to the FDA more frequently requiring risk mitigation programs for drugs and to the agency approaching approval decisions more conservatively. ${ }^{139}$ To make this argument, it is helpful to first understand why off-label promotion

a third example, the majority opinion in Caronia suggested that the FDA might choose to increase its own publicity efforts to counter any industry communications that are problematic in the agency's view. Caronia, 703 F.3d at 168. Indeed, the FDA clearly has the authority to communicate about the products that it regulates. See, e.g., 21 U.S.C. § 375(b) (2012); Nathan Cortez, Adverse Publicity by Administrative Agencies in the Internet Era, 2011 BYU L. REV. 1371, 1375, 1385 (2011); NATHAN CORTEZ, AgENCY PUBlicity IN THE INTERNET ERA 32 (Sept. 2015), https://www.acus.gov/sites/default/files/documents/ agency-publicity-in-the-internet-era.pdf [https://perma.cc/2AAY-WYK7] [hereinafter Cortez Report] (Report to the Administrative Conference of the United States). It, however, is difficult to imagine that agency publicity could cure relevant public health concerns associated with broader industry promotion. The drug and tobacco industry spend an immense amount of money on advertising, with the drug industry spending approximate $\$ 27$ billion per year and the tobacco industry (excluding e-cigarette and other electronic nicotine delivery system (ENDS) companies) spending approximately $\$ 9.5$ billion per year. Persuading the Prescribers: Pharmaceutical Industry Marketing and Its Influence on Physicians and Patients, PEW CharITABle TRS. (Nov. 11, 2013), http://www.pewtrusts.org/en/research-and-analysis/fact-sheets/2013/11/11/persuading-theprescribers-pharmaceutical-industry-marketing-and-its-influence-on-physicians-andpatients [https://perma.cc/7Z72-K7XM]; Tobacco Industry Marketing, CENTERS FOR DISEASE CONTROL $\&$ PREVENTION, http://www.cdc.gov/tobacco/data_statistics/fact sheets/tobacco industry/marketing/ [https://perma.cc/B56Y-WGQ8] (last updated Dec. 19, 2016). Each number dwarfs the FDA's entire budget-which was $\$ 4.9$ billion in 2016. U.S. FoOD \& DRUG ADMIN., FY 2016 PRESIDENT's BUDGET (Feb. 2015), https://www.fda.gov/ downloads/AboutFDA/ReportsManualsForms/Reports/BudgetReports/UCM432650.pdf [https://perma.cc/H8SZ-FWD3]. Particularly when information about risk is nuanced, as will often be the case for new drug and ENDS products, it is difficult to imagine that financially limited FDA publicity could overcome messages in sophisticated industry marketing with far greater resources behind it.

${ }^{139} \mathrm{Cf}$. FDA MEMO, supra note 17, at 2 ("The separate weighing of benefit and risk for each intended use is critical because evidence establishing effectiveness in one setting ... does not establish effectiveness of the same product in another setting ...."). 
poses public health concerns. Put simply, one reason is that off-label promotion may increase the risks of a drug. 140

Some off-label uses are medically important, as the FDA itself has acknowledged. ${ }^{141}$ For instance, off-label uses are important for certain subpopulations, such as children and pregnant women, because relatively few drugs are studied in, and approved for, those groups. ${ }^{142}$ And in some areas of medicine, such as oncology, off-label uses of drugs may be the standard of care in part because the research moves more quickly than the FDA approval process can and the drugs may be particularly likely to be effective against more than the one type of cancer. ${ }^{143}$

Nevertheless, broad off-label promotion can pose significant public health concerns. Research suggests that, even with the current limits on off-label promotion, over $70 \%$ of off-label prescriptions are for uses that lack strong scientific support. ${ }^{144}$ Such uses generally are associated with significantly

${ }^{140}$ For a full discussion of the FDA's public health concerns regarding off-label promotion, see FDA MEMO, supra note 17, at 4-5.

${ }^{141}$ U.S. FoOd \& DRUG ADMIN., GUIDANCE FOR INDUSTRY: Distributing SCIENTIFIC and Medical Publications on Unapproved New Uses-Recommended Practices 6 (Feb. 2014), http://www.fda.gov/downloads/drugs/guidancecomplianceregulatoryinformation /guidances/ucm387652.pdf [https://perma.cc/37ND-W5SQ] [hereinafter REPRINT GUIDANCE]; cf. Efthimios Parasidis, Patients over Politics: Addressing Legislative Failure in the Regulation of Medical Products, 2011 WIS. L. REV. 929, 985 (2011) (“Although drugs are widely prescribed for off-label indications and such uses are generally regarded as necessary to treat various health concerns, information related to the safety and effectiveness of offlabel uses is limited and has not undergone FDA scrutiny."). Of course, even if some offlabel uses are medically valuable, such uses are not likely to be widespread if insurers will not pay for them. But insurers do often pay for off-label uses for various reasons. As one example, federal law requires Medicare to pay for many drugs used off-label to treat cancer. See, e.g., Recent Developments in Medicare Coverage of Off-Label Cancer Therapies, $5 \mathrm{~J}$. ONCOLOGY PRAC. 18, 18 (2009), https://www.ncbi.nlm.nih.gov/pmc/articles/PMC2790627/ [https://perma.cc/J6LY-KVXM].

${ }^{142}$ See, e.g., Dominique Leveque, Off-Label Use of Anticancer Drug, 9 LANCET OnCOlOGY 1102, 1103 (2008); Annie Drapkin Lyerly et al., Pregnancy and Clinical Research, HASTINGS CTR. REP., Nov.-Dec. 2008, at 53.

143 See, e.g., Amy P. Abernethy et al., Systematic Review: Reliability of Compendia Methods for Off-Label Oncology Indications, 150 ANNALs INTERNAL MED. 336, 336 (2009); Off-Label Drug Use in Cancer Treatment, NAT'L CANCER INST. (Jan. 1, 2014), https://www.cancer.gov/about-cancer/treatment/drugs/off-label [https://perma.cc/HZ3TXXGW].

${ }^{144}$ See supra Eguale, Association, note 14, at 176; supra Eguale, Drug, note 14, at 783; David C. Radley et al., Off-Label Prescribing Among Office-Based Physicians, 166 ARCHIVES INTERNAL MED. 1021, 1023 (2006); see also Barbara J. Evans, What Will It Take To Reap the Clinical Benefits of Pharmacogenomics?, 61 FoOD \& DRUG L.J. 753, 785 (2006) (noting that "there may be a public health need to restrict some off-label uses of targeted therapies and TAB tests"). Despite the lack of strong evidence to support many off-label uses, insurers may pay for such off-label prescriptions, likely for several reasons, including that it can be difficult for insurers to distinguish between supported and unsupported offlabel uses, and between off-label and on-label uses. See, e.g., Abbott \& Ayres, supra note 
higher rates of adverse events than on-label uses, and physicians often are unaware that particular drug uses are off-label even when those uses lack scientific support. ${ }^{145}$ Additionally, many of the FDA's off-label-related enforcement actions have revealed concerning conduct in which drug companies have promoted risky off-label uses. ${ }^{146}$ Assuming that off-label promotion effectively increases off-label prescribing, ${ }^{147}$ such promotion, thus, may cause an increase in these riskier uses of drugs.

Because there is debate about what are, in fact, truthful and non-misleading statements about drugs, limiting protections to what courts determine to be truthful and non-misleading claims is not likely to address such public health concerns about off-label promotion. ${ }^{48}$ Courts may be willing to conclude that truthful and non-misleading promotion, in at least some circumstances, includes promotion about uses that lack significant scientific support. Amarin provides an example. Amarin sought to market Vascepta for lowering triglyceride levels in patients without severe hypertriglyceridemia with a statement that Vascepa "may reduce the risk of coronary heart disease." 149 But several clinical trials conducted to study the link between lowering lipid levels and lowering the risk of cardiovascular disease were inconclusive. ${ }^{150}$ Despite the lack of scientific support for asserting that a link between lowering lipid levels and the risk of cardiovascular disease exists, a federal judge concluded that Amarin's statement was permissible truthful and non-misleading promotion. ${ }^{151}$ And Amarin's claim about Vascepta is, of course, technically true - absent definitive evidence, we could say that anything may, or may not, be linked with a reduction in cardiovascular disease. ${ }^{152}$ The claim, however, in fact may be misleading, given that many likely understand the claim to be more definitive than it literally is,

18, at 392 ("Private insurers have attempted to restrict [off-label prescribing] by arguing that such prescriptions are not 'medically necessary,' but this tactic has met with limited success."); Joshua Cohen et al., Off-Label Use Reimbursement, 64 FOOD \& DRUG L.J. 391, 400 (2009) (describing the results of a 2009 study of insurers' policies on reimbursing offlabel uses); $c f$. Rachel Sachs, Administering Health Innovation, 39 CARDOZO L. REV. (forthcoming 2018) (manuscript at 23) (on file with author) (describing the relative lack of information sharing between the FDA and the Centers for Medicare and Medicaid Services on drug reimbursement).

145 See, e.g., Donna T. Chen et al., U.S. Physician Knowledge of the FDA-Approved Indications and Evidence Base for Commonly Prescribed Drugs: Results of a National Survey, 18 PharmacoePIDEMIOLOGY \& DRUG SAFETY 1094, 1094-99 (2009); Evans supra note 144 , at 768 .

146 See, e.g., supra notes 9-11 and accompanying text.

${ }^{147}$ It seems fair to make this assumption. After all, increasing off-label uses of drugs is likely to be one, if not the only goal, of a company's off-label promotion, and research has demonstrated that drug promotion influences prescribing practices. See, e.g., Wazana, supra note 13 , at 375 .

148 See, e.g., Hey \& Kesselheim, supra note 19, at 3.

149 See id. at 2.

150 See id.

151 Id.

${ }^{152}$ Id. 
and at the very least, the claim is uninformative. ${ }^{153}$ This result in Amarin demonstrates how what courts deem to be "truthful and non-misleading" promotion may nevertheless include promotion about uses of drugs that lack strong scientific support - and are likely to be riskier. ${ }^{154}$

The question, then, is how the FDA might address increased risks associated with drugs that are marketed off-label. This Part explores a few ways that the FDA could attempt to mitigate increased promotion-related risks of drugs, focusing on the FDA's authority to require Risk Evaluation and Mitigation Strategies (REMS) and its approval authority. In short, increased risks of drugs may alter the way that the FDA implements these authorities, possibly leading to undesirable policy consequences by restricting access to drugs or removing them from the market.

\section{Regulating the Practice of Medicine Through REMS}

In Caronia, the majority opinion noted that "less-speech restrictive" regulatory alternatives available to the FDA included "prohibit[ing] off-label use altogether" or capping the number of off-label prescriptions that physicians may write. ${ }^{155}$ As others have argued, these suggestions seem "ludicrous" for several reasons. ${ }^{156}$ With limited exceptions, the FDA generally does not have the statutory authority to directly regulate prescribing practices ${ }^{157}$ and has faced vigorous political opposition when it has been perceived as wading into medical practice oversight. ${ }^{158}$ Moreover, as already noted, the FDA recognizes that some

153 Id.

${ }^{154} C f$. Kesselheim \& Mello, supra note 16, at 1588 ("[E]ven when a ... document supporting a claim about the safety ... of an off-label use is offered, it may convey only a slice of the full empirical picture.").

155 United States v. Caronia, 703 F.3d 149, 168 (2d Cir. 2012).

156 Kesselheim \& Mello, supra note 16, at 1596.

157 See, e.g., id. at 1595 ("[D]irect regulation of the practice of medicine is outside the FDA's jurisdiction."); see also Lewis Grossman, Drugs, Biologics, and Devices: FDA Regulation, Intellectual Property, and Medical Products in the American Healthcare System, in The OXFord HANDBOOK OF U.S. HEAlth LAW 637 (I. Glenn Cohen et al. eds., 2016) (describing the FDA's indirect regulation of medical practice); Lars Noah, Ambivalent Commitments to Federalism in Controlling the Practice of Medicine, 53 U. KAN. L. REV. 149, 173 (2004) ("[T]he FDA undoubtedly affects the practice of medicine, even if only indirectly."); Zettler, supra note 35, at 460-64 (describing the FDA as indirectly regulating medical practice). But see 21 U.S.C. § 333(e) (2012) (expressly prohibiting off-label use of Human Growth Hormone).

${ }^{158}$ One example of political opposition to FDA regulation of medical practice comes from the history of the 1962 amendments to the FDCA. Drug Amendments of 1962, Pub. L. No. 87-781, §102(c), 76 Stat. 780, 781 (1962). The 1962 amendments gave the FDA authority to require that drugs be shown to be effective as well as safe. $I d$. This requirement for demonstrating effectiveness was opposed by the American Medical Association and others on the ground that it would interfere with physicians' individualized decisions about what treatments were in their patients' best interests. Zettler, supra note 35, at 475 . 
off-label uses are medically valuable. ${ }^{159}$ Thus, it is nearly impossible to imagine that the FDA would broadly prohibit all off-label uses (or cap the number of offlabel prescriptions a provider may write, which would do nothing to distinguish supported and unsupported uses), even if it had express statutory authority to do so.

But restrictions on off-label use are not unprecedented. Examples of federal limits on off-label use include the FDCA's prohibition on off-label prescribing of Human Growth Hormone (HGH) and the Controlled Substances Act's prohibition on prescribing certain controlled substances for "maintenance treatment" unless those drugs are approved for that indication. ${ }^{160}$ States have also limited off-label prescribing of certain drugs through legislation and regulation, consistent with states' long-recognized authority to regulate medical practice pursuant to their police powers. ${ }^{161}$

And it is not impossible to imagine that if - or when - expanded off-label promotion (and use) leads to increased risks associated with drugs, the FDA would make greater use of its authority to indirectly regulate medical practice through requiring Risk Evaluation and Mitigation Strategies (REMS) for prescription drugs. ${ }^{162}$ REMS are, essentially, special risk mitigation programs for drugs that the FDA can require drug manufacturers to implement and that go beyond including warnings or other information in a drug's FDA-approved labeling. ${ }^{163}$ The REMS may include, among other things, tools known as "elements to assure safe use" that require manufacturers to ensure that drug prescribers or dispensers have special training (e.g., about the risks of misuse and overdose associated with controlled substances), that the drug is dispensed only in certain settings (e.g., only in a hospital inpatient setting), or that certain tests results are documented before a drug is dispensed (e.g., a negative pregnancy test for a drug known to cause birth defects). ${ }^{164}$ Although the FDA has not explicitly used REMS to prohibit all off-label uses of a drug, some REMS appear to significantly restrict off-label uses, or at least make them more

${ }^{159}$ See, e.g., REPRINT GUIDANCE, supra note 141 , at 6.

160 Zettler, supra note 35 , at 456.

${ }^{161}$ Id. at 446; cf. Lars Noah, State Affronts to Federal Primacy in the Licensure of Pharmaceutical Products, 2016 Mich. ST. L. REV. 1, 3 (2016) (describing numerous state efforts to regulate drugs, sometimes through medical practice laws).

${ }^{162} \mathrm{Cf}$. Margaret Foster Riley, An Unfulfilled Promise: Changes Needed to the Drug Approval Process To Make Personalized Medicine a Reality, 70 FoOD \& DRUG L.J. 289, 308 (2015) ("In 2007, [the Food \& Drug Administration Amendments Act] introduced potentially far-reaching limits on the practice of medicine doctrine allowing FDA to impose restrictions (e.g. place and mode of use) on approved drugs . ...."); Sandburg, supra note 92, at 4 (quoting Scott Gottlieb - who was confirmed as the FDA Commissioner in May 2017as predicting that limiting FDA regulation of off-label promotion could lead to greater agency regulation of medical practice); Zettler, supra note 35, at 464, 498 (describing the FDA's REMS authority as indirectly regulating medical practice).

16321 U.S.C. § 355-1(d)-(f) (2012).

${ }^{164} I d . \S 355-1(\mathrm{f})(3)$ 
difficult. ${ }^{165}$ For example, the REMS for Entereg - a drug approved to accelerate recovery after certain bowel resection surgeries ${ }^{166}$-requires the manufacturer to ensure that Entereg is only "dispensed in a hospital in patient [sic] setting that performs bowel resection surgery," thereby limiting the ability of providers to utilize this drug for off-label uses. ${ }^{167}$ In this way, although it is drug manufacturers and not health care providers that are responsible for complying with REMS requirements, the FDA, nevertheless, can indirectly regulate offlabel uses. ${ }^{168}$

The FDCA authorizes the FDA to require a REMS when the agency determines that one is necessary to ensure that the benefits of a drug outweigh its risks. ${ }^{169}$ To the extent that broader off-label promotion and greater off-label use increase the risks of a drug, it, thus, is logical that the FDA would more frequently determine that a REMS is necessary to ensure a favorable benefitrisk ratio. In fact, in determining whether to require a REMS, the FDCA seems to broadly authorize the FDA to consider the risks of all off-label use in its REMS decisions. Specifically, the FDCA provides that the FDA should consider "any known or potential adverse events that may be related to the drug" without requiring an association with an on-label use. ${ }^{170}$ Additionally, the FDCA includes in its definition of adverse drug experiences relevant to the FDA's REMS decision-making off-label uses-such as "abuse" and "overdose... whether accidental or intentional," as well as any adverse drug event "occurring in the course of the use of the drug in professional practice." 171

Consistent with this language, the FDA has required REMS that aim to mitigate risks associated with off-label uses of drugs, including risks posed to individuals who are not prescribed the drug. For instance, one purpose of the REMS for transmucosal immediate release fentanyl products, which are powerful painkillers, is to "[prevent] accidental exposure to children and others for whom [the drugs are] not prescribed." 172 As another example, the goal of

165 See, e.g., Scott Gottlieb, Drug Safety Proposals and the Intrusion of Federal Regulation into Patient Freedom and Medical Practice, 26 HeALth AFF. 664, 672 (2007).

166 U.S. Food \& Drug Admin., Approved Labeling for Entereg (Oct. 2013), https://www.accessdata.fda.gov/drugsatfda_docs/label/2013/021775s010lbl.pdf [https://perma.cc/4SKU-SR8C].

167 U.S. Food \& Drug Admin., Approved Risk Evaluation and Mitigation Strategy (REMS) for Entereg (alvimopan) at 3 (June 2016), https://www.accessdata.fda.gov/ drugsatfda_docs/rems/Entereg_2016-06-01_REMS_document.pdf [https://perma.cc/S8C2P4TC] (database updated June 2016).

168 See, e.g., Evans, supra note 16, at 521; Zettler, supra note 35, at 460-66.

16921 U.S.C. $\S 355-1$ (a) (2012).

${ }^{170}$ Id. $\S 355-1(\mathrm{a})(1)(\mathrm{E})$.

${ }^{171}$ Id. $\$ 355-1(\mathrm{~b})(1)$.

172 U.S. Food \& Drug Admin., Approved Risk Evaluation and Mitigation Strategy (REMS) for Transmucosal Immediate Release Fentanyl (TIRF) at 2 (Aug. 2017), https://www.accessdata.fda.gov/drugsatfda_docs/rems/TIRF_2017-09-07_Full.pdf [https://perma.cc/LK2L-UQAD]. TIRF products are intended to be used for managing breakthrough pain in opioid-tolerant cancer patients and come in a variety of forms, 
REMS for Juxtapid, a cholesterol-lowering medication approved for patients with an inherited form of high cholesterol known as homozygous familial hypercholesterolemia (HoFH), is to mitigate the risk of serious liver injury associated with the drug. ${ }^{173}$ To accomplish this goal, the REMS aims to ensure that "JUXTAPID is dispensed only to patients with a clinical or laboratory diagnosis consistent with" HoFH; that is, the REMS appears intended to discourage off-label use of the drug in patient populations for which the benefitrisk ratio may not be favorable. ${ }^{174}$

If broader product promotion increases risky off-label uses, it, therefore, would be consistent with the FDCA and the FDA's previous decisions for the FDA to more frequently require REMS to address those risky uses. Indeed, an increase in the agency's use of REMS may be just what the Caronia majority envisioned (although not precisely in those terms) - rather than regulate drug manufacturers' speech to address risks of off-label promotion, the agency ought to more strictly regulate the products themselves, or the prescribing and dispensing of the products. This, in some views, is what the First Amendment requires.

But the FDA already requires REMS relatively often-according to the Generic Pharmaceutical Association, the agency requires REMS for about $40 \%$ of the novel drugs that it approves ${ }^{175}$ - and greater use of REMS (or greater use of the most restrictive elements in REMS) does not come without trade-offs. For instance, more REMS programs may create more opportunities for anticompetitive behavior. The FDA, lawmakers, and scholars have expressed concern that manufacturers of branded drugs use REMS to delay generic

including sublingual tablets and lozenges, which may increase the risk of accidental exposure to children. Id. at 4.

${ }^{173}$ U.S. Food \& Drug Admin., Approved Risk Evaluation and Mitigation Strategy (REMS) for Juxtapid (lomitapide) (Mar. 2017), https://www.accessdata.fda.gov/drugsatfda _docs/rems/Juxtapid_2017-03-02_REMS_Document.pdf [https://perma.cc/TA6Q-5PLR].

${ }^{174}$ See id.; see also Evans, supra note 16, at 520 (describing the effect of the mifepristone REMS on those patients seeking access for an off-label use).

${ }^{175}$ Alex Brill, Lost Prescription Drug Savings from Use of REMS Programs To Delay Generic Market Entry 1 (July 2014), http://www.gphaonline.org/media/cms/REMS Studyfinal_July2014.pdf [https://perma.cc/9HY3-P4PA]. 
competition in various ways. ${ }^{176}$ As one example, ${ }^{177}$ to obtain FDA approval of a generic drug, a company must demonstrate that the generic drug is bioequivalent to the branded version - and to conduct the necessary studies to make that showing, the generic company needs samples of the branded drug. ${ }^{178}$ Branded manufacturers reportedly have used REMS-required restrictions on a drug's distribution to deny a potential generic competitor access to samples of the drug, thereby making the bioequivalence testing necessary for FDA approval impossible. ${ }^{179}$ As another example, the default under the FDCA is that manufacturers of branded and generic versions of the same drug will use a single, shared system to implement the REMS for that drug. ${ }^{180}$ Branded manufacturers might drag out negotiations over that shared system, which delays the market entry of generic versions that cannot be sold until the REMS is in place. ${ }^{181}$ Particularly at a time when exorbitant drug prices are a significant policy concern, ${ }^{182}$ relying more heavily on REMS - thereby possibly decreasing

176 See, e.g., Michael A. Carrier, Sharing, Samples, and Generics: An Antitrust Framework, 103 CORNELL L. REV. (forthcoming 2017) (manuscript at 1), https://papers.ssrn.com/sol3/papers.cfm?abstract id=2979565 [https://perma.cc/Z4KD-3JCM]; Erika Lietzan, A Second Look at the CREATES Act: What's Not Being Said, 17 FEDERALIST SoC'Y REV. 38, 39 (2016); Jordan Paradise, REMS as a Competitive Tactic: Is Big Pharma Hijacking Drug Access and Patient Safety?, 15 Hous. J. Health L. \& Pol'y 43, 47 (2015); Ameet Sarpatwari et al., Using a Drug-Safety Tool To Prevent Competition, 370 New ENG. J. MeD. 1476, 1476-77 (2014); Scott Gottlieb, FDA Working To Lift Barriers to Generic Drug Competition, FDA VOICE (June 21, 2017), https://blogs.fda.gov/fdavoice/index.php/2017 /06/fda-working-to-lift-barriers-to-generic-drug-competition/ [https://perma.cc/XS2K-4YFD].

${ }^{177}$ For a full discussion of the ways that REMS might be used to thwart potential generic competition, see generally Carrier, supra note 176; Lietzan, supra note 176; Paradise, supra note 176; and Sarpatwari et al., supra note 176.

178 See, e.g., Paradise, supra note 176, at 47-50.

${ }^{179}$ See, e.g., Mylan Pharms. Inc. v. Celgene Corp., No. 14-2094, 2014 U.S. Dist. LEXIS 182222, at 12-13 (D.N.J. Dec. 22, 2014); Natco Pharma Ltd. v. Gilead Scis., Inc., Civ. No. 14-3247 (DWF/JSM), 2015 WL 5718398, at*1 (D. Minn. Sept. 29, 2015); In re Thalomid \& Revlimid, No. 14-6997, 2015 WL 9589217, at*1 (D.N.J. Oct. 29, 2015); Complaint at 19 2-4, Actelion Pharm. Ltd. v. Apotex, Inc, Civ. No. 05743 (D.N.J. filed Sept. 14, 2012); see also Lannett Co. v. Celgene Corp., No. 08-3920, 2011 WL 1193912, at*1 (E.D. Pa. Mar. 29,2011 ) (involving similar claims related to FDA-required restricted distribution systems that predated the agency's REMS authority). Efforts to prevent potential generic competitors from accessing branded drug samples are not limited to those drugs subject to a REMS. Manufacturers of branded drug samples may voluntarily restrict distribution of their product, or attempt to make access to samples difficult through contractual arrangements with distributors. See, e.g., Lietzan, supra note 176, at 45; Gottlieb, supra note 176.

18021 U.S.C. $\$ 355-1(i)(1)(B)(2012)$.

181 See, e.g., In re Suboxone, No. 2445, 2017 WL 36371, at*1 (E.D. Pa. Jan. 4, 2017); In re Suboxone, 64 F. Supp. 3d 665, 687 (E.D. Pa. 2014).

182 See, e.g., Aaron S. Kesselheim et al., The High Cost of Prescription Drugs in the United States: Origins and Prospects for Reform, 316 JAMA 858, 859 (2016); Rachel E. Sachs et al., Innovative Contracting for Pharmaceuticals and Medicaid's Best-Price Rule, 43 J. Health POL. POL'Y \& L. (forthcoming Feb. 2018), https://papers.ssrn.com/sol3/papers.cfm?abstract 
generic competition that can lower drug prices - may not be the optimal way to mitigate concerns about risky off-label uses. ${ }^{183}$

Beyond issues of competition and drug pricing, REMS may also involve trade-offs in medical care. Although REMS can be valuable tools for mitigating the risks of drugs, they also may impose burdens on patient access as well as the health care system more generally. Congress recognized this possibility, and required that REMS have elements to assure safe use "not be unduly burdensome on patient access" and "to the extent practicable ... minimize the burden on the health care delivery system." 184 If the FDA must more frequently rely on its REMS authority, rather than its off-label promotion policies, to mitigate the risks of off-label uses, patients, health care providers, and health care systems are likely to bear more of the load of that risk mitigation work. ${ }^{185}$

Relatedly, increased use of REMS would mean greater FDA involvement with the regulation of medical practice. States have long been viewed as the primary regulators of medical practice. ${ }^{186}$ But there is no constitutional bar on the FDA regulating in this space - the federal government could regulate medical practice under its commerce (and other) powers. ${ }^{187}$ Additionally, given the FDA's express authority to require REMS, there is no statutory obstacle to increased FDA involvement in medical practice through REMS. ${ }^{188}$ Indeed, courts have upheld FDA actions that, arguably, regulated medical practice, so long as the agency was acting within its statutory authority, ${ }^{189}$ and FDA, or other federal, regulation of medical practice may be warranted in certain circumstances. ${ }^{190}$ But heavier use of REMS, nevertheless, may lead to concerns about supplanting medical practitioners' judgments with those of the agency. Although the agency's assessment of how a drug should be used may be correct from a population health perspective, it may limit medical practitioners'

$\mathrm{id}=2959939$ [https://perma.cc/R334-6V43]; Patricia J. Zettler \& Erin C. Fuse Brown, The Challenge of Paying for Cost-Effective Cures, 23 AM. J. MANAGEd CARE 62, 62 (2017).

183 The Generic Pharmaceutical Association-which, of course, is not an unbiased stakeholder-estimates that the use of REMS to delay generic competition has increased pharmaceutical spending by over $\$ 5$ billion per year. See Brill, supra note 175 , at 1 .

18421 U.S.C. § 355-1(f)(2)(C)-(D) (2012); see also Evans, supra note 16, at 520 ("Congress was aware that REMS use restrictions could create problems of this sort.").

${ }^{185} \mathrm{Cf}$. Evans, supra note 16, at 515 ("[T] here are complaints that REMS will 'make drug lifecycle management more complex, more costly, and resource intensive.'”).

186 See, e.g., id. at 500-01; Zettler, supra note 35, at 434.

187 See, e.g., Evans, supra note 16; Noah, supra note 157, at 191-92; Orentlicher, supra note 19 , at 100 ; Zettler, supra note 35 , at 467 .

188 See, e.g., Zettler, supra note 24, at 874; Zettler, supra note 35, at 462.

189 See, e.g., United States v. Kaplan, 836 F.3d 1199, 1204, 1212, 1217 (9th Cir. 2016) (affirming the FDA's enforcement action against a doctor who reused needles labeled for single-use, on the theory the needles were adulterated); United States v. Regenerative Scis., LLC, 741 F.3d 1314, 1326 (D.C. Cir. 2014) (affirming an injunction against practitioners who provided autologous stem cell treatments in violation of the FDCA); see also Zettler, supra note 24, at 886 (discussing the ways in which the distinction between medical practice and medical products regulation is blurred).

190 See, e.g., Zettler, supra note 35, at 487-88. 
discretion in individual cases in a clinically meaningful way. ${ }^{191}$ Particularly when patients may increasingly seek autonomy over their health care decisions and desire more choices in their medical care, ${ }^{192}$ influencing clinical care based on a public health policy goal, rather than an individual patient's best interests, may be politically challenging. ${ }^{193}$

\section{Approval}

In addition to increasing the prevalence of REMS, broader off-label promotion may have the effect of making the standard for new drug approval more difficult to satisfy, at least for marginal drugs. ${ }^{194}$ New drugs may not be sold in the United States until the FDA approves them as safe and effective, and the FDA may withdraw approval of a previously approved drug if it no longer meets that approval standard (among other reasons). ${ }^{195}$ The FDA has long interpreted the safety and effectiveness standard for drug approval to mean that a drug's benefits outweigh its risks. ${ }^{196}$ To help ensure that the benefits of a drug outweigh its risks, the FDA can take a number of steps to monitor and mitigate a drug's risks post-approval, including requiring warnings in a drug's labeling, patient-specific labeling known as medication guides, postapproval studies and clinical trials, and REMS (as discussed above). ${ }^{197}$ The agency also conducts ongoing monitoring of the safety of approved drugs through an active postmarket risk assessment system and reported adverse events. ${ }^{198}$ FDA restrictions on prescription drug promotion, including on off-label promotion, are another tool for the agency to mitigate the risks of a drug. ${ }^{199}$ The FDA's policies on drug promotion are intended, among other things, to help ensure that accurate information is disseminated for safe use of the drugs. ${ }^{200}$ Thus, if the

${ }^{191}$ See, e.g., id.

192 See, e.g., Lewis A. Grossman, FDA and the Rise of the Empowered Consumer, 66 ADMIN. L. REV. 627, 675 (2014).

${ }^{193}$ See, e.g., Zettler, supra note 35 , at $487-88$.

${ }^{194}$ Many of the arguments in this Part may extend to other medical products including, as previously noted, devices. For simplicity and clarity, this Article focuses on prescription drugs.

19521 U.S.C. § 355(a), (d), (e) (2012). Generic drugs subject to an abbreviated new drug application (ANDA) are approved under a different standard based on the generic drug's similarity to the relevant branded drug. See id. § 355(j).

${ }^{196}$ Michelle Meadows, Promoting Safe and Effective Drugs for 100 Years, FDA CONSUMER MAG. (Jan.-Feb. 2006), https://www.fda.gov/aboutfda/whatwedo/history/

productregulation/promotingsafeandeffectivedrugsfor100years/ [https://perma.cc/SBN72FXC]; see also 21 U.S.C. § 355(d).

197 See, e.g., 21 U.S.C. $\S \S 355($ o)(3)-(4), 355-1; 21 C.F.R. $\S 208.1(\mathrm{~b})-(\mathrm{c})(2015)$.

198 See, e.g., 21 U.S.C. $\S 355(\mathrm{k})(3) ; 21$ C.F.R. $\$ 314.80$.

199 See, e.g., The Office of Prescription Drug Promotion (OPDP), U.S. FoOD \& DRUG ADMIN., https://fda/gov/aboutfda/centersoffices/officeofmedicalproductsandtobacco/cder/ ucm090142.htm [https://perma.cc/QBE6-PF35].

${ }^{200} \mathrm{Id}$. 
FDA's ability to oversee drug promotion is significantly limited, that may affect how the agency views a drug's safety for the purpose of weighing its risks and benefits in approval decisions.

Of course, whether broader off-label promotion, in fact, could affect the FDA's approval decisions depends on whether the FDCA permits the FDA to deny (or withdraw) approval based on the risks associated with off-label uses. One might argue that the FDCA does not authorize the FDA to consider the risks of off-label use in these decisions. This is because the statute provides that the FDA will approve a drug when, among other things, the manufacturer shows that the "drug is safe for use under the conditions prescribed, recommended, or suggested in the proposed labeling." 201

Although the statutory interpretation question deserves a deeper analysis than this Article can provide, it is worth noting that this statutory language cannot be considered in a vacuum, divorced from the rest of the FDCA. Considering the current language of the FDCA as a whole, ${ }^{202}$ there are strong signs that Congress did not intend the FDA to limit its evaluation of a drug's safety to risks associated with on-label uses, including in the context of approval and withdrawal decisions. ${ }^{203}$

One example comes from the requirements for reporting safety-related information to the agency. As part of a new drug application, a company must submit, "full reports of investigations which have been made to show whether or not [a] drug is safe for use,"204 and after approval companies must also submit to the agency "adverse drug experience information." 205 Neither reporting requirement is limited to information about the risks of on-label uses. ${ }^{206}$ That information about the risks of off-label uses is required to be submitted suggests that the FDA ought to use that information in its benefit-risk evaluations.

As another example, the changes to the FDCA made in the recently enacted 21st Century Cures Act further bolster the argument that Congress generally

20121 U.S.C. § 355(d) (emphasis added); see also Am. Pharm. Ass'n v. Mathews, 530 F.2d 1054, 1055 (D.C. Cir. 1976) (McGowan, J., concurring) (arguing, based on 21 U.S.C. $\S 355(\mathrm{~d})$, that "methadone is safe for its intended use notwithstanding the possibility that it will be employed in unintended fashions").

202 ANTONIn SCAlia \& Bryan A. Garner, READING LAW: THE INTERPRETATION OF LEGAL TEXTS 167-69 (2012) (describing the "whole act" canon of statutory interpretation).

203 See National ACAdEmies of Sciences, EngineERING, ANd Medicine, Pain MANAGEMENT AND THE OPIOID EPIDEMIC: BALANCING SOCIETAL AND INDIVIDUAL BENEFITS AND RISKS OF PRESCRIPTION OPIOID USE 6-17 to -21 (Richard J. Bonnie et al. eds., prepublication copy 2017) [hereinafter NAS REPORT] (describing the broad "public health dimensions" of the FDA's regulation of drugs, including its approval and withdrawal decisions); see also Richard J. Bonnie et al., Both Urgency and Balance Needed in Addressing Opioid Epidemic: A Report from the National Academies of Sciences, Engineering, and Medicine, 318 JAMA 423, 423-24 (2017) (describing a "comprehensive approach" for opioid approval decisions).

20421 U.S.C. $\S 355(b)$.

20521 C.F.R. $\S 314.80$ (a), (c) (2015).

20621 U.S.C. § 355(b); 21 C.F.R. § 314.80(a), (c). 
intends the FDA to consider a broad range of evidence in its approval decisions. The 21st Century Cures Act explicitly authorizes the agency to consider "real world evidence" and "patient experience data" in certain approval decisions. ${ }^{207}$ Both of these are forms of evidence that may include information on uses that deviate from those recommended in a drug's current or proposed labeling.

As a final example, as discussed in Part IV.A.1., Congress has authorized the FDA to consider the risks of off-label uses for the purpose of requiring a REMS. ${ }^{208}$ A REMS may be required when necessary to ensure that the benefits of a drug outweigh its risks. ${ }^{209}$ In other words, the FDA may require a REMS when necessary to ensure that a drug satisfies the approval standard. ${ }^{210} \mathrm{It}$, therefore, may be illogical to conclude that Congress intended the FDA to consider the risks of off-label uses when requiring REMS, but not when making approval decisions - particularly in light of the other evidence that Congress may not have intended to so limit the FDA. ${ }^{211}$

Moreover, as a practical matter, the FDA appears to consider the risks of off-label uses as part of its benefit-risk evaluations for approvals and withdrawals, at least in certain circumstances. In discussing the FDA's role in addressing the opioid crisis, the FDA Commissioner and the director of the FDA's Center for Drug Evaluation and Research explained that, "[w]henever FDA assesses the benefits and risks of a product, it must make certain that its decision making is based on all of the available information." 212 For approval and withdrawal decisions about opioids, this means that the FDA must consider how opioids are actually used, including when that use deviates from the FDAapproved labeling. ${ }^{213}$

Although opioid misuse and overdose is a particularly pressing and highprofile public health problem that may make it an unusual case, the FDA also seems to have considered the risks of off-label uses in its approval and withdrawal decisions in other contexts. One example is a 2011 FDA action on acetaminophen, an active ingredient in many prescription painkillers, such as Vicodin, and over-the-counter painkillers, such as Tylenol. ${ }^{214}$ Acetaminophen is associated with a risk of serious liver injury and is a leading cause of acute

207 21st Century Cures Act, Pub. L. No. 114-255, §§ 3001, 3022, 130 Stat. 1033, 1083, 1096 (2016).

20821 U.S.C. $\S 355-1(a)(1)(E),(b)(1)$.

209 Id. § 355-1(a).

210 See, e.g., Lietzan, supra note 176, at 42 ("[T] he agency may require a REMS only if the drug would not be approvable without the REMS in place.").

${ }^{211}$ Cf. Green v. Bock Laundry Mach. Co., 490 U.S. 504, 509, 527 (1989) (declining to read a statutory provision literally when doing so would result in "odd" or "absurd" results); SCALIA \& GARNER, supra note 202, at 234 (describing the "avoiding absurdity" canon of statutory interpretation).

212 Scott Gottlieb \& Janet Woodcock, Marshaling FDA Benefit-Risk Expertise To Address the Current Opioid Abuse Epidemic, 318 JAMA 421, 421 (2017) (emphasis added).

213 See id.

${ }^{214}$ See NAS REPORT, supra note 203 , at 6-20 to -21 . 
liver failure in the United States. ${ }^{215}$ After many years of attempting to address the risk of liver damage associated with acetaminophen through other means, the FDA published a Federal Register Notice announcing that the FDA would withdraw approval of prescription acetaminophen products with more than 325 milligrams of the ingredient in a dosage unit (e.g., pill) if manufacturers did not voluntarily lower the amount of acetaminophen. ${ }^{216}$ The agency's rationale for this withdrawal decision included the agency's concerns about the risks associated with patients taking more acetaminophen than recommended in the drug's labeling. ${ }^{217}$

It, therefore, seems plausible that if the FDA anticipates that unsupported off-label uses will be more widely promoted and more widely prescribed, that may change the agency's benefit-risk calculus at the time of approval. ${ }^{218}$ Imagine, for example, a drug that is demonstrated to be highly effective for weight loss, but also is associated with rare, but serious and even fatal, cardiovascular risks. Despite such serious risks, the benefits of such a drug might outweigh the risks for patients with obesity or severe obesity, because of the serious health risks associated with the conditions themselves. ${ }^{219}$ But it also seems likely that an effective weight loss drug-even one associated with serious risks - would be appealing to many individuals, including those without obesity, because of cultural pressures to be thin. The FDA might be less likely to approve such a drug, even with a REMS, knowing it could be promoted off-

215 Prescription Drug Products Containing Acetaminophen; Actions To Reduce Liver Injury from Unintentional Overdose, 76 Fed. Reg. 2691, 2691 (Jan. 14, 2011).

216 Id. at 2692. FDA's previous attempts to address the problem included working with the National Association of State Boards of Pharmacy to more clearly label prescription medications that contain acetaminophen, a 2002 advisory committee meeting regarding over-the-counter (OTC) acetaminophen products, a patient-education campaign launched in 2004 , an internal working group on acetaminophen started in 2007, changes to OTC drug labeling required in 2009, and another advisory committee meeting in 2009 focused on both OTC and prescription products. Id. at 2692-94.

217 Id. at 2692.

${ }^{218}$ Cf. United States v. Caronia, 703 F.3d 149, 179 (2d Cir. 2012) (Livingston, J., dissenting) ("[A]llowing drug manufacturers to promote off-label uses would undermine the FDA's approval process for not only new uses of pre-approved drugs, but also for entirely new drugs."); United States v. Caputo, 517 F.3d 935, 939 (7th Cir. 2008) ("Yet if a manufacturer's promise to the FDA to avoid speech about off-label uses is unenforceable, the FDA may respond by withholding any approval of drugs or devices that have questionable additional uses."). As a practical matter, this change in the agency's riskbenefit assessment might increase the amount, or change the kind, of data that the FDA views as necessary to satisfy the approval standard, which, de facto, may make the standard more difficult to meet. $C f$. NAS REPORT, supra note 203, at 6-26 to -32 (recommending that the FDA consider a broad range of data in its approval decisions regarding opioids, including data about unapproved uses).

219 See, e.g., Adult Obesity Causes \& Consequences, CENTERS FOR DiSEASE CONTROL \& PREVENTION (Aug. 15, 2016), https://www.cdc.gov/obesity/adult/causes.html [https://perma.cc/ C95B-4FE3] (discussing obesity as a serious health issue associated with an increased risk of various conditions such as heart disease and certain types of cancer). 
label, albeit "truthfully." Indeed, the FDA has explained that "[t]he separate weighing of benefit and risk for each intended use is critical" for the agency's approval decisions. ${ }^{220}$

Making this scenario more convincing, the agency is not likely to be able to effectively mitigate its concerns about off-label promotion by obtaining commitments not to market from companies at the time of approval. Even in areas without First Amendment concerns, the FDA has faced challenges enforcing approval conditions once a product is on the market. For example, questions have been raised about the FDA's ability to enforce postmarket studies and clinical trials of drugs that the agency required or drug companies committed to conduct, and similar concerns have been raised about the enforcement of REMS requirements. ${ }^{221}$

Relatedly, we might see an increase in the FDA withdrawing drug approvals. The FDA rarely uses its authority to formally withdraw approval of a new drug, ${ }^{222}$ likely for various reasons. These include that withdrawing approval is "not normally desirable if some patients [a]re benefitting from the drug despite its risks" 223 and, as noted above, the FDA is authorized to require a number of less drastic means of mitigating drug risks after approval such as requiring REMS and warnings on drug labeling. ${ }^{224}$ Additionally, the FDA does not often need to rely on its formal withdrawal authority because companies often voluntarily stop marketing drugs when faced with serious safety and effectiveness concerns. ${ }^{225}$ Nevertheless, if broader off-label promotion does

${ }^{220}$ FDA MEMO, supra note 17 , at 2-3.

${ }^{221}$ See Kevin Fain et al., The Food and Drug Administration Amendments Act and Postmarketing Commitments, 310 JAMA 202, 202-03 (2013); OFFICE OF INSPECTOR GEN., U.S. DEP'T HEALTh \& HuMAN SERVS., OEI-04-11-00510, FDA LACKS COMPREHENSIVE DATA TO DETERMINE Whether Risk EVALUATION AND Mitigation STRATEGIES IMPROVE DRUG SAFETY 14-22 (Feb. 2013), https://oig.hhs.gov/oei/reports/oei-04-11-00510.pdf [https://perma.cc/RGM3-T863].

222 Cf. Kurt R. Karst, How Often Are Drugs Withdrawn for Safety or Effectiveness Reasons (and How Many)? Not Too Often in Recent Years, but There Is a Tranche of Withdrawals Historically, HYMAN, PHELPS \& MCNAMARA, P.C.: FDA LAW BLOG (June 14, 2015), http://www.fdalawblog.net/fda_law_blog_hyman_phelps/2015/06/how-often-aredrugs-withdrawn-for-safety-or-effectiveness-reasons-and-how-many-not-too-often-inrece.html [https://perma.cc/3TWU-76WA] (finding that approximately $5 \%$ of the time that companies discontinue marketing brand-name drugs that generic companies seek to copy, FDA determines that it was for reasons of safety or effectiveness and withdraws approval of the application).

${ }^{223}$ U.S. FOOD \& DRUG AdMIN., GUIDANCE FOR INDUSTRY: SAFETY LABELING Changes-Implementation of Section 505(o)(4) of the FD\&C ACt 3 (July 2013), http://www.fda.gov/downloads/drugs/guidancecomplianceregulatoryinformation/guidances /ucm250783.pdf [https://perma.cc/5NNK-MB7G].

${ }^{224}$ See, e.g., 21 U.S.C. §§ 355(o)(4), 355-1(a)(2)(A) (2012).

225 See, e.g., FDA Public Health Advisory: Safety of Vioxx, U.S. FoOD \& DRUG ADMIN. (Sept. 30, 2004), http://www.fda.gov/Drugs/DrugSafety/PostmarketDrugSafetyInformationfor PatientsandProviders/ucm106274.htm [https://perma.cc/PS45-5A2D] (explaining that Merck voluntarily withdrew Vioxx from the market because of cardiovascular risks). 
increase the risks of drugs, we might expect to see the FDA more frequently withdrawing approval of drugs, if its other risk mitigation tools prove unsuccessful. Again, imagine the effective weight loss drug associated with serious cardiovascular risks. Given its benefits for patients with obesity or severe obesity, a more plausible scenario than the FDA denying approval, might be the FDA withdrawing approval if, after marketing, it becomes apparent that the drug's risks, including the risks of off-label use, outweigh its benefits.

To be clear, there is debate about whether the FDA's current implementation of the approval standard strikes the right balance, with some researchers and commentators raising concerns that the FDA's approval standard is too lenient, ${ }^{226}$ and others arguing that the FDA's standard for approval is too stringent. ${ }^{227}$ This Article does not attempt to enter that debate. Rather, this Article suggests that whatever the appropriate interpretation of the drug approval standard is, increased protections for off-label promotion may make it more difficult for the FDA to implement that interpretation of the approval standard by removing one tool for the agency to mitigate a drug's risks after approval.

Additionally, regardless of whether the mechanism would be fewer approvals or more withdrawals after approval (or both), as with REMS such an outcome does not come without trade-offs. The practical result of fewer approvals or more withdrawals, of course, would be that there are fewer approved drugs available for patients. This result is undesirable for various reasons, including that patients who might otherwise have had available

226 See, e.g., Chul Kim \& Vinay Prasad, Strength of Validation for Surrogate Endpoints Used in the US Food and Drug Administration's Approval of Oncology Drugs, 91 MAYO ClinIC Proc. 713, 723 (2016); David Gorski, Donald Trump Versus the FDA: Is the Standard of Evidence for Drug Approval Actually Too Low Rather than Too High?, SCIENCE-BASED MED. (Feb. 6, 2017), https://sciencebasedmedicine.org/donald-trump-versusthe-fda-part-2/ [https://perma.cc/WGE3-QWLF]; Matthew Herper, The FDA Is Basically Approving Everything. Here's the Data To Prove It, ForBES (Aug. 20, 2015), https://www.forbes.com/sites/matthewherper/2015/08/20/the-fda-is-basically-approvingeverything-heres-the-data-to-prove-it/\#65b42fb45e0a [https://perma.cc/X9YS-9C8R]; see also Nicholas S. Downing et al., Clinical Trial Evidence Supporting FDA Approval of Novel Therapeutic Agents, 2005-2012, 311 JAMA 368, 368-69 (2014) (finding that the quality of the evidence supporting drug approvals varies widely); Nicholas S. Downing et al., Postmarket Safety Events Among Novel Therapeutics Approved by the U.S. Food and Drug Administration Between 2001 and 2010,317 JAMA 1854, 1854 (2017) (finding that roughly one-third of novel drugs approved by the FDA were associated with significant postmarket safety concerns).

${ }^{227}$ See, e.g., Robert Kocher \& Bryan Roberts, The Calculus of Cures, 370 NEw ENG. J. MED. 1473, 1474 (2014); Leah Isakov et al., Is the FDA Too Conservative or Too Aggressive?: A Bayesian Decision Analysis of Clinical Trial Design 1 (Nat'l Bureau of Econ. Research, Working Paper No. 21499, 2015), https://papers.ssrn.com/sol3/papers.cfm?abstract_id=2641547 [https://perma.cc/E42DXDPM]; cf. Patricia J. Zettler \& Henry T. Greely, The Strange Allure of State "Right-ToTry Laws," 174 JAMA InTERNAL MED. 1885, 1885 (2014) (describing the debate around terminally and seriously ill patients' access to unapproved drugs). 
treatments - or more treatment choices - will not have them, and fewer drug approvals (or more withdrawals) may, in some instances, lead to less competition and higher drug prices. ${ }^{228}$

There may also be other, less obvious, trade-offs to consider. For example, there may be transparency concerns about shifting more risk management to drug approval decisions because there, arguably, is little oversight of FDA decisions not to approve drugs. Companies rarely, if ever, challenge those decisions in court, and the FDA's letter explaining its reasons for denying approval-known as a "Complete Response Letter"-generally is not publicly available under current FDA policies. ${ }^{229}$

Also, again similar to the REMS context, if the FDA becomes more conservative in its approval decisions, or more aggressive in exercising its withdrawal authority, the agency is likely to face political pressure. Indeed, in recent years, there have been instances of controversial drug approval and withdrawal decisions during which the FDA faced intense pressure. One example was the FDA's 2016 decision to approve Exondys 51-a treatment for Duchenne Muscular Dystrophy_despite slim support for its efficacy, after patient advocates conducted a vigorous campaign in favor of the drug's approval. ${ }^{230}$ As another example - and one in which the FDA made a decision different than the one sought by many patient advocates, some of whom protested outside the agency — in 2011 the FDA withdrew approval of the breast cancer indication for Avastin after postapproval research failed to confirm a clinical benefit associated with its effect on a surrogate endpoint. ${ }^{231}$ With increased interest in patient-focused drug development (and sophisticated, sometimes industry-funded, patient advocacy organizations), ${ }^{232}$ such pressures are likely to increase, especially if the approval standard appears to become more difficult to satisfy.

${ }^{228}$ Cf. Grossman, supra note 192, at 630 (describing patients' desire for choice); Scott Gottlieb, Comm'r, U.S. Food \& Drug Admin., Opening Remarks for Part 15 Public Meeting on Generic Drug Competition (July 18, 2017), https://www.fda.gov/NewsEvents/ Speeches/ucm567323.htm [https://perma.cc/P6VV-T8WD] (discussing the role of competition in drug pricing).

${ }^{229}$ See 21 C.F.R. $\S 314.430$ (2015).

230 See, e.g., Matthew Herper, Approving a Muscular Dystrophy Drug Ignites a Civil War at the FDA, FORBES (Sept. 20, 2016), https://www.forbes.com/sites/matthewherper/ 2016/09/20/approving-a-muscular-dystrophy-drug-ignites-civil-war-at-the-fda/\#5d1e10 5572a8 [https://perma.cc/MN74-ZJBQ].

231 See, e.g., Andrew Pollack, F.D.A. Revokes Approval of Avastin for Use as Breast Cancer Drug, N.Y. TIMES (Nov. 18, 2011), http://www.nytimes.com/2011/11/19/business/ fda-revokes-approval-of-avastin-as-breast-cancer-drug.html [https://perma.cc/8GFR-ETLY].

232 See, e.g., Matthew S. McCoy et al., Conflicts of Interest for Patient-Advocacy Organizations, 376 NEw ENG. J. MeD. 880, 880-82 (2017); Susannah L. Rose et al., Patient Advocacy Organizations, Industry Funding, and Conflicts of Interest, 177 JAMA INTERNAL MED. 344, 345 (2017); The Voice of the Patient: A Series of Reports from FDA's PatientFocused Drug Development Initiative, U.S. FoOD \& DRUG ADMIN. (May 3, 2017), https://www.fda.gov/forindustry/userfees/prescriptiondruguserfee/ucm368342.htm [https://perma.cc/4YQA-QUGS]. 


\section{B. Other Consequences: The Example of New Tobacco Product Approval}

Expanded protection for off-label promotion also could affect FDA regulation outside of the prescription drug context, as well as outside of the medical products context altogether. This is because the First Amendment protections that may result in broader promotion of prescription drugs, likewise, may lead to broader promotion of other FDA-regulated products than FDA policies might otherwise permit. 233 FDA regulation of tobacco products - and in particular Electronic Nicotine Delivery Systems (ENDS), a popular novel tobacco technology that includes e-cigarettes - may provide one example of how such expanded product promotion might affect FDA regulation of a nonmedical product. ${ }^{234}$ This Part begins to undertake an exploration of what those effects might be in this context, albeit a preliminary exploration because the FDA's jurisdiction over ENDS is relatively new and experience with how the FDA will exercise its authority over ENDS is limited.

The Family Smoking Prevention and Tobacco Control Act of 2009 amended the FDCA to authorize the FDA to regulate tobacco products. Among other things, it created an FDA approval process for "new tobacco products," which include "any tobacco product ... that was not commercially marketed in the United States as of February 15, 2007." 235 Because most ENDS have entered the U.S. market more recently than 2007, many ENDS will be new tobacco products required to undergo the FDA's premarket review process. ${ }^{236}$ To obtain an order from the FDA authorizing marketing under a premarket tobacco product application (PMTA), a company must demonstrate to the FDA that "permitting [its] tobacco product to be marketed would be appropriate for the protection of the public health." 237 The statute further specifies that the FDA will make this public health determination

${ }^{233}$ See infra notes $243-44$ and accompanying text.

234 This Article focuses only on those ENDS that meet the definition of tobacco products under the law. See 21 U.S.C. § 321(rr) (2012). Some ENDS may not be tobacco products. ENDS marketed for therapeutic purposes - for example, for smoking cessation —or ENDS that deliver synthetic nicotine not derived from tobacco may be drugs, devices, or drugdevice combination products under the FDCA. See 21 U.S.C. § 321(g), (h); Sottera, Inc. v. FDA, 627 F.3d 891, 898 (D.C. Cir. 2010); Patricia J. Zettler et al., Closing the Regulatory Gap for Synthetic Nicotine, 59 B.C. L. REV. (forthcoming 2018) (on file with author).

23521 U.S.C. $\S 387 \mathrm{j}(\mathrm{a})(1)$; Deeming Tobacco Products To Be Subject to the FDCA, 81 Fed. Reg. 28,974 (May 10, 2016) (to be codified at 21 CFR pts. 1100, 1140, and 1143).

236 See 81 Fed. Reg. 28,974, 28,976.

23721 U.S.C. $\$ 387 \mathrm{j}(\mathrm{c})(2)(\mathrm{A})$. The Family Smoking Prevention and Tobacco Control Act also created a "substantial equivalence" pathway for obtaining the FDA's authorization to market new tobacco products. $I d$. $\S 387 \mathrm{j}(\mathrm{a})(3)$. This pathway is available to products that have the same characteristics as a "predicate" tobacco product, or that have different characteristics but do not raise "different questions of public health." Id. Products that may be used as predicates are those that were legally marketed in the United States as of February 15,2007 , or those that go through the substantial equivalence pathway to obtain marketing 
with respect to the risks and benefits to the population as a whole, including users and nonusers of the tobacco product, and taking into account-

(A) the increased or decreased likelihood that existing users of tobacco products will stop using such products; and

(B) the increased or decreased likelihood that those who do not use tobacco products will start using such products. ${ }^{238}$

There is little experience with how the FDA will implement this "public health" standard for PMTAs for various reasons. The FDA, thus far, has issued marketing orders for only eight new tobacco products under this standard. ${ }^{239}$ Additionally, it was not until 2016 that the FDA deemed many novel tobacco technologies, such as ENDS, to be subject to the premarket approval requirement. ${ }^{240}$ Moreover, the FDA does not intend to enforce premarket review requirements for many current ENDS until 2022. ${ }^{241}$ Nevertheless it is clear that the standard for issuing a PMTA marketing order requires the FDA to weigh product risks and benefits, broadly conceived to include the risks and benefits to both users and nonusers of the product.

authorization. See U.S. FoOd \& DRUG AdMIN., GUIDANCE FOR INDUSTRY AND FDA STAFF: Section 905(J) Reports: Demonstrating Substantial EQuivalence for Tobacco PRODUCTS 4 (Jan. 2011), https://www.fda.gov/downloads/TobaccoProducts/

Labeling/RulesRegulationsGuidance/UCM239021.pdf [https:/perma.cc/LSZ8-Z2GB]. Because ENDS products were not generally marketed in the United States as of February 2007, it is unlikely that ENDS manufacturers will be able to make use of the substantial equivalence pathway to marketing. For that reason, this Article focuses on the standard for approval for PMTAs.

23821 U.S.C. $\S 387 \mathrm{j}(\mathrm{c})(4)$.

239 Tobacco Product Marketing Orders, U.S. Food \& DRUG ADMIN. (May 8, 2017), http://www.fda.gov/TobaccoProducts/Labeling/TobaccoProductReviewEvaluation/ucm339 928.htm [https://perma.cc/P59S-9LYS]. All eight approved products are versions of Swedish Match North America's smokeless tobacco, "Snus." See Premarket Tobacco Product Marketing Orders, U.S. FoOD \& DRUG ADMIN. (Nov. 10, 2015), http://www.fda.gov/TobaccoProducts/Labeling/TobaccoProductReviewEvaluation/ucm472 108.htm [https://perma.cc/A6W7-RVWM].

240 See Deeming Tobacco Products To Be Subject to the FDCA, 81 Fed. Reg. 28,974, 28,984 (May 10, 2016) (to be codified at 21 CFR pts. 1100, 1140, and 1143).

${ }^{241}$ In a July 2017 statement the FDA announced that it would not enforce the requirement for premarket review until 2022 for ENDS products that were on the U.S. market as of August 2016. See Press Release, U.S. Food \& Drug Admin., FDA Announces Comprehensive Regulatory Plan To Shift Trajectory of Tobacco-Related Disease, Death (July 28, 2017), https://www.fda.gov/NewsEvents/Newsroom/PressAnnouncements/ ucm568923.htm [https://perma.cc/RKX7-6HL2]. For compliance dates for ENDS products that first entered the market after August 2016, see U.S. FOOD \& DRUG ADMIN., GUIDANCE FOR INDUSTRY: EXTENSION OF CERTAIN TOBACCO PRODUCT COMPLIANCE DEAdLINES RELATED TO THE FInAL DEEMING RULE (Aug. 2017), https://www.fda.gov/downloads/ TobaccoProducts/Labeling/RulesRegulationsGuidance/UCM557716.pdf [https://perma.cc/VTR4YZ8Z]. 
Although there are many open questions about the risks and benefits of ENDS for users and exposed nonusers, and the FDA will evaluate the merits of each product individually, researchers have suggested that we can draw a few general conclusions. Mainly, ENDS appear to be less harmful than traditional cigarettes, but also addictive, more harmful than no nicotine or tobacco exposure at all would be, and, so far, of uncertain value for influencing smokers to reduce or quit their cigarette consumption. ${ }^{242}$ This suggests that in a marketing order analysis, the FDA might consider whether a specific ENDS product has attributes making it likely to be used by current smokers as a less harmful means of using nicotine, which would be a public health benefit. The FDA might also consider whether an ENDS product is likely to initiate tobacco and nicotine use among nonsmokers, which would pose a public health risk.

One way to assure the FDA that the smoking reduction benefits of an ENDS might be maximized, and the initiation risks minimized, would be to limit advertising either to current smokers (or a subset of current smokers) or to restrict the content of advertising in some way to encourage smokers to use the ENDS as a cigarette replacement. ${ }^{243}$ In addition to potentially shaping the benefits of the products, ENDS product promotion could increase risks associated with the products, particularly in light of the evidence that tobacco marketing can be quite effective at initiating tobacco use among adolescents and young adults. ${ }^{244}$ The FDA's benefit-risk evaluation of new tobacco products, as with drugs, thus might be shaped by how products are promoted and the agency's ability to oversee that promotion.

To the extent the First Amendment allows, the FDCA expressly authorizes the FDA to restrict tobacco product advertising and promotion to protect the public health. ${ }^{245}$ In light of the fact that the FDA has had some success in defending the restrictions on tobacco product promotion imposed in the FDCA, the FDA may be better positioned to enforce restrictions on the promotion of approved tobacco products than it is to enforce its policies related to off-label promotion of drugs. For example, the FDCA requires that the FDA authorize

${ }^{242}$ See, e.g., Eric N. Lindblom, Effectively Regulating E-Cigarettes and Their Advertising — and the First Amendment, 70 FOOD \& DRUG L.J. 55, 55 (2015); see also Wendy E. Parmet, Paternalism, Self-Governance, and Public Health: The Case of E-Cigarettes, 70 U. MIAMI L. REV. 879, 881 (2016) ("The increasing popularity of e-cigarettes offers either a novel tool for further reductions in cigarette use or a dangerous lure that may lead a new generation to smoke."); Scott R. Weaver et al., Use of Electronic Nicotine Delivery Systems and Other Tobacco Products Among USA Adults, 2014: Results from a National Survey, 61 INT. J. PUB. HEALTH 177, 177 (2016) ("The public health challenge is how to enhance the potential that ENDS can replace combusted tobacco products without expanding nicotine use among youth, long-term ex-smokers, and other vulnerable populations.”).

243 See Lindblom, supra note 242, at 62.

244 See, e.g., U.S. DeP'T HeAlth \& Human Servis., Preventing Tobacco Use Among Youth AND Young AdULTS: A RePORT OF THE SURGEON GENERAL 508 (2012), http://www.cdc.gov/tobacco/data_statistics/sgr/2012/index.htm [https://perma.cc/U4HZXFPD].

24521 U.S.C. $\$ 387 f(d)(1)(2012)$. 
marketing for "modified risk tobacco products"- those products accompanied by claims that they reduce the harms associated with tobacco products - and, relying on Central Hudson, the Sixth Circuit concluded that requirement, on its face, did not violate the First Amendment. ${ }^{246}$ Additionally, if the FDA decided to restrict ENDS advertising to certain audiences (e.g., ENDS companies may only market to current smokers, but may say whatever they wish in that marketing), such restrictions, if imposed, may not be construed as content-based restrictions subject to heightened scrutiny. ${ }^{247}$ Finally, as practical matters, the long and well-known history of misleading tobacco advertising in the United States, and the agency's explicit statutory authority to restrict tobacco product promotion for public health reasons, may make courts more sympathetic to FDA regulation than they are in the drug context. ${ }^{248}$

Nevertheless, Caronia and its progeny may raise concerns that once the FDA permits a new tobacco product to enter the market, restrictions on advertising and promotion may be struck down when they are applied to specific claims that courts deem to be truthful and non-misleading promotion. Given scientific uncertainty about the risks and benefits of ENDS products, ${ }^{249}$ ENDS manufacturers may be able to craft marketing campaigns that, like Amarin's promotion of Vascepta, are deemed truthful and non-misleading by a court but nevertheless pose public health concerns. ${ }^{250}$ Moreover, as in the drug context, the fact that a company may promise at the time the FDA issues a marketing order to limit its product promotion is not likely to be helpful. It would be challenging for the agency to enforce such a commitment. ${ }^{251}$

To the extent that the FDA faces difficulty in enforcing promotion restrictions after new tobacco products enter the market, the FDA, thus, may more conservatively exercise its authority to issue, or more aggressively exercise its authority to withdraw, 252 tobacco product marketing orders. The practical effect would be the same as for drugs-fewer products on the market than there might otherwise be - and this outcome may not be a desirable one for the public health. Smoking remains the leading cause of preventable death in

${ }^{246}$ Id. § 387k; Disc. Tobacco City \& Lottery, Inc. v. United States, 674 F.3d 509, 534 (6th Cir. 2012); see also Nathan Cortez, Do Graphic Tobacco Warnings Violate the First Amendment?, 64 HASTINGS L.J. 1467, 1483 (2013) ("[D]oes the requirement that the FDA preapprove marketing for 'modified risk' tobacco products . . . violate the First Amendment? (No.)."). Modified risk claims include statements such as "light" and "mild," or, as one company has proposed, "No tobacco product is safe, but this product presents substantially lower risks to health than cigarettes." See Modified Risk Tobacco Products, U.S. FoOD \& DRUG ADMIN., http://www.fda.gov/TobaccoProducts/Labeling/TobaccoProduct

ReviewEvaluation/ucm304465.htm [https://perma.cc/3NNV-2H4J] (last updated June 26, 2017).

247 See Lindblom, supra note 242.

248 See, e.g., Disc. Tobacco City \& Lottery, 674 F.3d at 534.

249 See supra note 242 and accompanying text.

250 See supra notes 148-54 and accompanying text.

251 See supra note 221 and accompanying text.

25221 U.S.C. § $387 \mathrm{j}$ (d) (2012). 
the United States, causing roughly 480,000 deaths per year. ${ }^{253}$ If the potential harm reduction benefits of ENDS and other novel tobacco products can be realized, such products could have a significant, positive impact on the public health by reducing smoking-related death and disease, and fewer products on the market may lessen that impact.

\section{CONCLUSION}

This Article suggests that the impact of recently recognized protections for off-label promotion - even if limited to what courts deem to be truthful and nonmisleading promotion about approved products - could affect FDA oversight outside of its product-promotion regulatory regimes. This effect is not limited to the context of medical products. Broader product promotion may alter any FDA regulatory decisions that involve weighing product risks and benefits, at least at the margins, because such promotion may increase the risks associated with the products. This, in turn, may lead to more limited access to FDAregulated products, which is not likely to be a desirable outcome for any stakeholders.

Although an undesirable policy outcome cannot trump protections for offlabel promotion grounded in the First Amendment, there may be creative, practical steps that the FDA and other stakeholders could take to mitigate potential indirect effects of off-label use. One possibility is that the FDA could explore ways that it might cooperate with other stakeholders that influence how drugs are used to mitigate the risks of unsupported off-label uses. ${ }^{254}$ Perhaps most obviously, health insurers are stakeholders that can shape how prescription drugs are used-if insurers will not pay for particular uses, those uses are likely to be reduced or eliminated. ${ }^{255}$ Moreover, regardless of the steps that the FDA and other stakeholders might take, this Article may provide another reason for courts to take seriously the government's position that it has a substantial interest in regulating off-label promotion, and to give that interest significant weight in First Amendment analyses.

253 See, e.g., Diseases and Death, Centers for Disease Control \& Prevention, https://www.cdc.gov/tobacco/data statistics/fact sheets/fast facts/index.htm

[https://perma.cc/S3DS-6R52] (last updated Mar. 29, 2017).

${ }^{254} \mathrm{Cf}$. Sachs, supra note 144 (discussing the benefits of interagency cooperation for health innovation).

${ }^{255}$ See, e.g., Dresser \& Frader, supra note 17, at 483 ("Federal officials could adopt more rigorous policies on reimbursement for off-label uses, limiting Medicare and Medicaid payments to off-label uses that are either supported by solid evidence or administered in the context of clinical trials evaluating their safety and effectiveness."); Rebecca S. Eisenberg \& W. Nicholson Price II, Promoting Healthcare Innovation on the Demand Side, 4 J.L. \& BIOSCIENCES 3, 18-19 (2017) (discussing opportunities for health care payers to evaluate the bases for off-label use and pay for them selectively). 
